THE LAST SHIP: REPATRIATION FROM BRITISH GUIANA TO INDIA by

Nalini Mohabir, B.Sc., University of Toronto, 1995

\author{
A Major Research Paper \\ presented to Ryerson University
}

in partial fulfillment of the requirements of the degree of

\author{
Masters of Arts \\ in the Program of \\ Immigration and Settlement Studies
}

Toronto, Ontario, Canada, 2006

(C) Nalini Mohabir 2006 
UMI Number: EC53525

INFORMATION TO USERS

The quality of this reproduction is dependent upon the quality of the copy submitted. Broken or indistinct print, colored or poor quality illustrations and photographs, print bleed-through, substandard margins, and improper alignment can adversely affect reproduction.

In the unlikely event that the author did not send a complete manuscript and there are missing pages, these will be noted. Also, if unauthorized copyright material had to be removed, a note will indicate the deletion.

\section{$\mathrm{UMI}^{\circ}$}

UMI Microform EC53525

Copyright 2009 by ProQuest LLC

All rights reserved. This microform edition is protected against unauthorized copying under Title 17, United States Code.

ProQuest LLC

789 East Eisenhower Parkway

P.O. Box 1346

Ann Arbor, MI 48106-1346 
I hereby declare that I am the sole author of this major research paper.

I authorize Ryerson University to lend this paper to other institutions or individuals for the purpose of scholarly research.

Signature

I further authorize Ryerson University to reproduce this paper by photocopying or by other means, in total or in part, at the request of other institutions or individuals for the purpose of scholarly research.

Signature 


\title{
THE LAST SHIP: REPATRIATION FROM BRITISH GUIANA TO INDIA
}

(C) Nalini Mohabir 2006

\author{
Master of Arts \\ Immigration and Settlement Studies \\ Ryerson University
}

\begin{abstract}
In 1955 the ship, the M.V. Resurgent, took the last group of ex-indentured Indo-Caribbean labourers back to India. This was a closing chapter on Indo-Caribbean Indentureship, whereby thousands of Indians came to Caribbean shores between 1838 and 1917. Indian indentured labourers had arrived to work British Caribbean plantations, with a "right to return" to India built into their indenture contracts. The clause did not specify a time limit on claims. Four decades after the abolition of Indentureship, a number of ex-indentured labourers from British Guianese plantations and their families opted to take the last ship back to a recently liberated India. This recovered history through the lived experiences of the last Repatriation Officer, Chhablal Ramcharan is located within the emancipatory energy of postcolonial scholarship, and uses narrative, memory and archives to contribute to an understanding of Indo-Caribbean migration, settlement, and diasporic identities.
\end{abstract}

Keywords:

Indo-Caribbean Diaspora; Return Migration; Indentured Labour 


\section{Acknowledgements}

Thank you to Aja whose hand guided me throughout this process. I give heartfelt thanks to my advisor, Dr. Hyacinth Simpson, for helping me to understand in ways too numerous to list. As well, thanks to Dr. Frank Birbalsingh and Martin Latchana for bringing Aja's story to public attention. I am also very grateful to Dr. Myer Siemiatycki for his warm encouragement. I appreciate the helpful suggestions of Dr. Joe Springer, and am thankful to Shelanda Wilson for offering her comments. I am also grateful to the late Guyanese Minister Satyadeow Sawh for his support. In addition, I would like to acknowledge BWIA West Indies Airways for their support of this research. Staff at the National Archives of Guyana, the Cheddi Jagan Research Centre and the University of Guyana gave invaluable assistance. Last but not least, I would like to thank my family and friends for their love and support, without which this would not be possible.

\section{Dedication}

In memory of Aja,

Chhablal Ramcharan (1918-2006). 
Introduction......

.1

Chapter 1: Historical Background and Concerns of Diaspora.

.4

Chapter 2: Return Journey.........................................................22

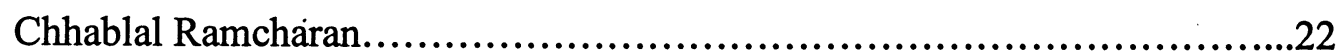

Memory, History and Communal Identity....................................24

Literature and History ................................................27

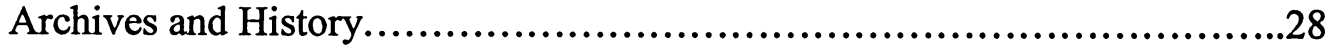

Return Narratives: Literature.............................................29

Return Narratives: Contested................................................32

The Role of the Immigration Office.........................................34

Indian Independence and The Last Return....................................36

Decolonisation: Guiana...................................................45

Decolonisation: India.....................................................49

Chapter 3: "Going Home...to a home they never saw."..............................53

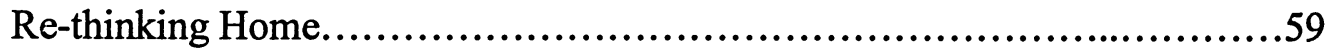

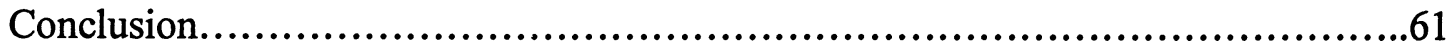

Works Cited....................................................................65

Notes.......................................................................... 76 


\section{THE LAST SHIP: REPATRIATION FROM BRITISH GUIANA TO INDIA}

\section{INTRODUCTION}

The impetus for this research can be traced to a series of conversations between the author and Chhablal Ramcharan about his role in British Guiana's ${ }^{1}$ last repatriation of indentured Indian labourers undertaken in 1955. Ramcharan, born May 12, 1918, and raised in Plantation Albion, British Guiana (now Guyana), served in that country's Immigration Office from 1944 to 1960. The highlight of his civil service career was his appointment as Repatriation Officer on board the last ship returning formerly indentured labourers to India. This paper incorporates Ramcharan's memories, which he shared over the course of the summer of 2005, of the events surrounding that last journey. Those memories serve as a rare firsthand account of an important moment in Caribbean history (Mohabir and Simpson 489).

Sadly, those conversations ended abruptly with his passing, but they were more than "old talk"; those conversations exemplify the importance of tapping into the oral history of the Caribbean held in the memories of eiders, as well as the power of communal acts of remembering to orient our understanding of diasporas, and diasporic identities to the specificities of the Indo-Caribbean experience (Simpson). This paper recovers an oral historical account of the last repatriation journey of Indian indentured labourers from British Guiana to India and draws on the details of this account to discuss what return migration journeys reveal about the intricacies and complexities of personal and communal identity formation and how those identities get reformulated as individuals and communities settle in specific locations.

Reconstructing the last return journey primarily though the voice of an Indo-Caribbean participant holds significance for several reasons. For one, Ramcharan's narrative provides a more liberating version of history from the perspective of the subaltern by recalling, reclaiming 
and empowering submerged Indian ancestral and diasporic voices in the Caribbean. For another, self-generated narratives also have the power to deconstruct discourses of domination by addressing the gaps and silences in relation to subaltern lives in official and archival records, thereby shedding more light on the lived experiences of dominated peoples. In addition, narratives told "from the ground up" are not simply facts but a "new take" on previously held assumptions (hooks 147). The importance of recovering the history of the last official repatriation journey is underscored by the well-known Indo-Caribbean writer Samuel Selvon who declared that "The full story in all its detail is worthy of record, setting out both facts and figures with analysis and description of the times in which it occurred" ("Three"16).

This papers attempts to address Selvon's challenge by balancing the scholarly requirements of a major research paper with the development of an accurate historical record. The aim is twofold: 1) to recover the facts of the journey as told through Ramcharan and archival documents; and 2) to better understand the reasons for, and significance of, the final return. In regard to the latter, the last return journey is an important part of understanding Caribbean history and culture as it exemplifies the inherent tensions of Indo-Caribbean diasporic identity, caught between two home spaces, two cultures: the Caribbean and India.

Current uses of the term "Indo-Caribbean" capture some of these inherent tensions. The term is used primarily outside of the Caribbean and replaces the term "East Indian," which was used in colonial times. This shift from an ethnic identifier to a hyphenated identity that places the ethnic within a new cultural location raises several questions including, "How can one be both one and something other?" (Radhakrishnan 120). The answer, Puri suggests, is that hyphenated identities represent a break with, rather than connection between, nations or cultures (27). The implications of this response-including the possibility that returning labourers would necessarily 
experience difficulty upon attempting re-settlement in India because their sense of identity was largely shaped by their Caribbean experience even though they were ethno-racially Indian-will be explored in this paper.

This paper begins with an overview of the history of Indentureship analysed within a diasporic framework, then moves on to recover the story of the M.V. Resurgent's voyage from British Guiana to India in 1955 by juxtaposing Ramcharan's oral account with traditional archival material-newspaper accounts and colonial documents-and ends with a discussion of how the return journey and the events surrounding it contribute to a better understanding of IndoCaribbean migration, settlement and diasporic identities. 


\section{CHAPTER 1: Historical BACKgROUND AND CONCERNS OF DiASPORA}

No single event occurs in isolation; therefore, to more fully understand the last repatriation journey it has to be discussed within the context of other historical events and colonial initiatives that impacted on it. This chapter will draw primarily upon existing Caribbean scholarship to recreate this context. In addition, diasporic theories and concepts are employed to draw attention to themes emerging from the return journey in particular and more generally how it is that diasporic communities negotiate between "here" (their current place of settlement) and "there" (their birth or ancestral homelands); the nature of the trauma associated with immigration and/or exile and subsequent returns; and how such communities' sense of belonging, home(land) and identity get affected by journeys out and in.

Diaspora theory is multifaceted; a unified theory of diaspora does not exist, rather definitions of diaspora are contested (Braziel and Mannur 4; Butler 189). Butler's definition of diaspora as "the dispersal of people from their original homeland" across two or more nations is a simple starting point (189). Despite generalisable aspects of diaspora theory, it is important to bear in mind that all diasporas are rooted in specific social, cultural and political histories.

The linguistic origin of the term diaspora derived from the Greek verb speiro "to sow" and the preposition dia "over" conveys the image of "a scattering of seeds" (Cohen ix). According to Brah, a notion of dispersion requires a centre or a home from which one was originally scattered (181), intimating a connection between the originary homeland (centre) and its dispersed population-if not physically at least in memory or imagination. This dialectic relation between dispersal and centre is associated in the West primarily with the Jewish community, but also with other forced or involuntary diasporas such as the African, Palestinian 
and Armenian communities (Cohen ix). The term diaspora may also aptly describe dispersal from the Indian sub-continent, connected to a range of movements, such as colonial labour displacements to rubber, tea, sugar plantations or railways or later postcolonial immigration or refugee movements.

Implicit in the idea of a non-voluntary dispersal is exile from homeland. In fact, the history of diaspora theory stems from the experience of the Jewish diaspora; the original use of diaspora referred to the biblical experience of Jewish exile. Loss, yearning or desire to return stemming from the experience of exile helps to locate the site of, and shifts in, home(land). The paper will demonstrate that tension between homes, manifested in exile, trauma, and return is integral to understanding Indo-Caribbean diasporic identity.

The last repatriation of 1955 is situated within a history of involuntary migration of indentured labourers from India to the sugar estates of the Caribbean. Many scholars call for the retrieval of Indo-Caribbean narratives from the margins of (Caribbean) history as part of the process of decolonising history (Ramdin ix); that is, to write history from the perspective of community experiences as opposed to dominant European or American colonial frameworks (Dei and Asgharzadeh 299). Thus, the following historical account begins with the experiences of British Guiana, as opposed to the original dispersion from Indian homeland, as emphasising the primacy of 'Motherland' would collude with perceptions of an essentialised Indian-ness.

Many authors describe the migration of indentured labourers as involuntary on the basis that those who made the journey were manipulated or intimidated into doing so or outrightly abducted by arkatis (recruiters) working on behalf of and serving the interests of colonial rulers (Persaud 177; Laurence 47; Ramdin 18; Ray 271). Although narratives of trickery and deception 
are common to Caribbean history, it is important to note that the involuntary migration of indentured labourers is qualitatively different from the process of chained enslavement that Africans underwent even prior to boarding outward ships. Perhaps this difference allowed colonial administrators to view Indentureship as voluntary induction into the "civilising influence" of the British Empire, and as a means of uplifting the "heathens" and "inferior races" (Carter and Torabully 52). Yet stories of treacherous recruitment practices, passed down through generations of families, persist to this day (Ramdin 18). Some diaspora researchers frame Indian indentured migration as a voluntary labour diaspora citing the search for work as a push factor (Cohen 57; Singh 297). However, this paper stresses the aspects of involuntary migration because independent movement did not exist under conditions of colonisation, i.e. this was a diaspora created through forces of colonial domination.

Many historical documents refer to Indians in the Caribbean as immigrants (e.g., Comins); however this paper employs the identifying term "Indian indentured labourers" in concurrence with Puri's argument that "immigrant" masks the subordinate conditions of Indentureship under which Indians arrived (65). Immigration options for Indians in the nineteenth century were tightly controlled; for example, immigration to the British settler territory of Canada (or Australia or New Zealand) was open to mainly white immigrants in the nineteenth and most of the twentieth century (Ramdin 8$).{ }^{2}$ Non-white immigration to Canada was officially discouraged until 1967; thus a perceived freedom of movement implied in the term immigrant would be deceptive.

Indian migration to the Caribbean under Indentureship is more aptly understood as an "imperial labor reallocation" as they were brought to meet the needs of plantation owners after the abolition of slavery (Kale 5). The Emancipation of slaves did not end the plantocracy's (i.e., 
governance by the planter class) reliance on coerced labour; plantation owners merely sought other forms of exploited labour to continue capitalist production. Although the system of Indentureship began almost as soon as Slavery ended and was considered a form of neo-slavery by contemporary observers, ${ }^{3}$ there were important codified distinctions (Rabe 18). Under the extremely violent conditions of Slavery, lasting as an institution for four hundred years, Africans were treated as property, enslaved for life and their children born into Slavery. They were never given an option to return. ${ }^{4}$ After Slavery, plantation owners attempted to attract freed slaves to work on plantations under a transitional Apprenticeship program (semi-slavery), but the African population resisted (Ramdin 6). Hence, planters began to look elsewhere for cheap labour (i.e., neo-slavery). ${ }^{5}$

In general, the history of the Caribbean is a brutal history of forced labour, inextricably linked to sugar, for the purpose of economic expansion of the Empire. Prior to African enslavement, the indigenous population of Guiana was subjected to slavery, followed by a trade in European domestic servants (Ramdin 2). After Slavery ended in 1834, plantation owners sought to indenture liberated Africans (1840-1867), as well as to indenture labourers from other countries such as Portugal, i.e., mostly Madeira (1835-1882) and China (1853-1879). In 1874, the Cantonese government suspended the recruitment of Chinese indentured labourers to Guiana due to the colony's failure to provide return passage home (Jacob 41; J. Ruhomon 62-64). In China, Guiana became known as "a land from whence no one returned," thus indicating the importance of return to passage to the entire system of Indentureship (Clementi qtd. in J. Ruhomon 64). The history of Indian indentured labourers in Guiana is not only an extension of this history, but also occurred within a distinctive set of relations between India and Guiana. 
India was the main source of labourers indentured to plantations. A combination of factors made India a reliable source of labour, including British policies that destroyed communal land and family farming resulting in famine and unemployment (Ramdin 11-12); the stereotyping of Indians as a servile and "obedient race" (Ramdin 11); and the British policy of "shunting labour [in the Empire] here, there and...everywhere" (Ramdin 7). In total, nearly half a million Indians were recruited under terms of Indentureship to the British Caribbean (Williams 348). This paper focuses on Indo-Caribbeans in British Guiana (although to give a comprehensive account information on other Indo-Caribbean communities in Trinidad and Jamaica is also referenced). With 238,969 indentured Indians arriving between 1838 and 1917, Guiana had the largest presence of Indians in the Caribbean (Dabydeen 28), or even in the entire Western hemisphere (Rabe 3). Other sugar colonies such as Trinidad and Jamaica also received Indian indentured labourers, as did the smaller exploited islands like St. Lucia, Nevis, St. Vincent and Grenada (Ramdin 16; 175), but of all the British Caribbean countries to import Indian indentured labour, Guiana had the longest history (eighty years), and some say, the most brutal (Naipaul, The Middle Passage 118).

The movement of Indian indentured labourers to the Caribbean first began as a business request from British Guianese plantation owner Sir John Gladstone (owner of Plantations Vreeden Hoop and Vreedestein) to a firm in Calcutta in 1836 through his "placing an order" for one hundred "Bengalees" to work on his sugar estates (Scoble 4). Thereafter, Indentureship was organised under colonial auspices, and Indians were brought across the Kala Pani (dark waters of the ocean) almost continuously from 1838 till the end of the Indentureship system in $1917 .^{6}$ After their initiation into Indentureship and a lengthy voyage into the Caribbean, Indian labourers were confined to the sugar cane fields for the term of their indenture contract, usually five years, after 
which the debt owing for passage to the colony was considered paid. Another five years of service was required to cover the costs of return passage "home" (Ray 271). Thus, the desire to return evident among Indentured labourers was actually legislated into their Indenture/migration experience by colonial authorities.

The earliest indenture/ship to set anchor in Georgetown (capital of British Guiana) was the Whitby (a wooden ship weighing 350 tons) which sailed in 1838 from Calcutta (Nath 10) and brought the first "East Indian West Indians" (Selvon, "Three" 21). Thereafter, British shipping lines Nourse and Sandbach Tinne and Company were engaged in a steady "coolie ${ }^{7}$ carrying trade" (Ramesar 184). The early "coolie clippers" took up to six months to sail from India, around the southern coast of Africa, and across the Atlantic to the West Indies (Ramesar 186), carrying their cargo in the hulks of ships (Mishra, "Diasporic Imaginary" 429). Bound labour traveled in the bounded space of merchant ships, and consequently ships became a symbol of exploitation in the minds of indentured labourers and their descendants (Shepherd, Maharani 16).

Gilroy in his discussion of the Black Atlantic Slave Trade uses the image of ships to represent the diasporic flows and circulations between and through different points in the (Black) Atlantic. He writes:

I have settled on the image of ships in motion across the spaces between Europe, America, Africa, and the Caribbean as a central organising symbol for this enterprise and as my starting point. The image of the ship-a living, microcultural, micro-political system in motion-is especially important for historical and theoretical reasons...Ships immediately focus attention on the Middle Passage, on the various projects for redemptive return to an African homeland...(52-53) 
By drawing attention to the role of ships, Gilroy implies ships are not only vessels of exploitative relationships used to transport the means of production (i.e. black and brown bodies) to the Caribbean, and later transport the goods they produced (i.e. sugar) to European markets, but also that ships were physical sites of resistance ("a living, microcultural, micro-political system in motion") and a metaphor for hope ("redemptive return") for Caribbean people, generally speaking.

The option of return to India upon completion of the indentureship contract ("the right of return") was an important legal obligation. It was, as Laurence notes, "the most scrupulously observed" of all colonial responsibilities to indentured Indians (362), most likely because the promise of return passage home was instrumental to a steady recruitment of labour. Any exindentured Indian labourer in possession of a "Certificate of Exemption from Labour" documenting fulfillment of his or her indenture contract was eligible for return, if he or she desired. ${ }^{8}$ In the early years, indentured labourers could claim free return passage after five years, then later (post-1854) after 10 years; after 1895 return passage was not free, but subsidised (Ramesar 183-184). The right of return was intended for indentured labourers and eventually their families (after 1894 offspring irrespective of age or place of birth were also eligible for return) ${ }^{9}$ (Laurence 382). Indo-Caribbeans born in the colony (and therefore not indentured) were not eligible for (subsidised) return passage unless they were traveling with formerly indentured parents or spouses. The obligation for assisting with return came to a close after Indentureship ended; the last repatriation from Jamaica was in 1929 (Shepherd, "Poverty" 102), and 1936 from Trinidad (Laurence 540). However, the abolition of Indentureship did not mean the end of ties between India and British Guiana,${ }^{10}$ as Guiana remained the only colony in the British Caribbean not to impose a time limit on the right to return (Laurence 381). 
The first return ships to sail were the Louisa Baillie and the Water Ditch departing in 1843 (Nath 19), followed later by steam ships which cut the six-month journey nearly in half. Between 1850 and 1929, a return ship departed almost annually from Georgetown (Laurence 539). Seventy-five thousand indentured adults and their families (approximately $32 \%$ of all Indians including offspring) returned to India from British Guiana (Seecharan, "Indo-Caribbean People" 73). The last two return ships (the Orna in 1949 and the Resurgent in 1955) were modern motor vehicles, and took little over a month to reach their destination (Mangru, Indians 51-52), following the same path back across the Kala Pani around the Pagla Samundar ("mad sea," off the ironically named Cape of Good Hope) back to Calcutta (Laurence 363). Yet, even with the regular sailing of return ships and despite arriving as temporary labour, the vast majority (i.e., three-quarters) of indentured Indians remained in the Caribbean (Williams 352).

Although homeward bound ships of indentured labourers have attracted less attention than the initial vessels that sailed from India, return ships are important literally and symbolically because they provide evidence of: 1) the one (perhaps the only) area in which a marginalised people could assert their rights; and 2) the importance of a circular flow-a journey out coupled with a journey back in - of migration to an Indo-Caribbean diasporic consciousness specifically. and to a Caribbean consciousness more generally. In fact, narratives of return (i.e. return as hope, belonging, redemption, fate or desire) is a signifier of the very experience of being Caribbean (Hall 243). Moreover, in an Indo-Caribbean context, return ships allows an exploration of questions of "home"-where it is and how it is conceived.

Settler or temporary sojourner, the right of return was significant to the Indo-Caribbean psyche. Initially, the right to return to India was instrumental in persuading indentured labourers to leave their villages, as British Guiana was especially far from home (Rabe 22). Likewise, the 
hope of return sustained indentured labourers over a decade or more spent toiling under the harrowing conditions of plantations. The sense of hope that return afforded as a means of escaping "coolie status" cannot be underestimated. Sir Arthur Gordon, Governor of British Guiana, attributed high suicide rates in the colony to a notion of hopelessness or "an intense desire to return to India which they [indentured labourers] had no means of gratifying" (Singh, T. qtd. in Mishra, "Bordering Naipaul" 201). Some new recruits determined to find a way back even sought overland routes to Calcutta, only to become disoriented in Guiana's tropical rainforest (Nath 76). Whether indentured labourers remained or returned, emotional expressions of hope embodied in return is an important aspect of the Indo-Caribbean narrative, and of diasporas more generally.

Whereas the right of return was important to indentured labourers, the contractual obligation was viewed differently by planters. Paternalistic ideas and selfish economic arguments led planters to periodically attempt to dispense with the right of return, questioning the wisdom of the labourers' desire to leave "industry" and "progress" in the West to return to famine or poverty in India; or otherwise, the planters viewed the return obligation as a financial burden to the colony (Comins 9-12; Mangru, El Dorado 55). Despite pressures from planters, the government of India never waived the right of return, as it was the only measure to ensure the safety and welfare of indentured Indians abroad; or, as Mangru notes, the return clause was an "escape hatch to freedom and insurance against planter tyranny" (El Dorado 61). Thus, for indentured labourers, the option to return was also a means of asserting their limited rights.

Working conditions on the sugar estates were controlled by an odious "plantation logic" which determined where indentured labourers lived (i.e., logies, the former slave barracks), worked (sugar cane fields), spent free time (e.g., rum diverted attention from social conditions), ${ }^{11}$ 
and meted out swift punishment for any transgressions (e.g. leaving the estate without permission) (Lamming xxii). ${ }^{12}$ Williams notably described Indentureship as "freedom plus a constable" as the principal inducements to labour were the stocks or jail (356). Towards the end of the nineteenth century and into the twentieth century when indentured workers began to collectively rise up and protest conditions on plantations, periodic shootings were used to enforce colonial order (Seecharan, "Indo-Caribbean People" 70). Sharma suggests the plantation experience contributed to the unique aspects of the Indo-Caribbean diaspora, especially in regard to the violations of dignity that produced an Indo-Caribbean consciousness (55).

Universalist theories of diaspora overlook the specifics of a plantation setting, but understanding the traumas of Plantation and "coolie" life is important to distinguish between the Indo-Caribbean diaspora and other (Indian) diasporas (Mishra, "Bordering Naipaul" 190). General theories often name the loss of homeland as traumatic, but for Indo-Caribbeans, Mishra locates trauma more specifically in the space of ships, passage, and barracks ("Impossible Mourning" 34). "Coolie" traumas (e.g., the deception of the arkatis, victimisation by owners of the sugar industry, cruelty of overseers) are experiences that haunt Indo-Caribbean diasporic communities and consciousness. Mishra demands that the collective trauma of Indentureship becomes central to Indo-Caribbean narratives as part of an "ethical relationship to ghosts of the diaspora" ("Impossible Mourning" 28). Failure to keep ghosts alive serves to weaken diaspora theory (Mishra, "Impossible Mourning" 31). Building upon psychoanalytic theories of repressed trauma, Mishra views memories of trauma as "haunting" because they reside primarily in the subconscious - not yet fully acknowledged in the conscious.

Mishra acknowledges challenges in naming moments of trauma in the past; however, the danger of failing to admit trauma is an incomplete account of history ("Impossible Mourning" 
34). Furthermore, there is no solution to trauma if it remains an abstract concept (Mishra, "Impossible Mourning" 37). In diaspora, mourning cannot be separated from trauma, though it is not a pathological process, but rather psychological. Mourning is witnessed in the gaps of history; mourning is represented by metaphors (e.g. the ship); mourning is read into absences of memory. The "cure" to mourning is to come to terms with specific loss and traumas (Mishra, "Impossible Mourning" 30).

Mishra also classifies the Indian diaspora into "old" and "new" to recognise the different traumas that separate the newer South Asian diaspora from the older Indian diaspora. Movement of skilled South Asian professionals (e.g., from India, Pakistan, and Bangladesh, excluding refugee movements from Sri Lanka) are prompted by the advanced capitalist needs of settler states and former imperial centres ("Impossible Mourning" 25-26). The older diaspora, however, is a consequence of classic capitalism, i.e., the indentured labourer whose movements were tied to cheap labour requirements of plantation-based economies in the South ("Impossible Mourning" 26). In Canada, both diasporas meet and consequently are lumped together, but "race" as a homogenising construct is not an adequate representation of the disparate psychological, cultural, historical, colonial and postcolonial experiences of the old and new diasporas.

Signs of transformation from old homeland identities to a new Indo-Caribbean identity began to emerge even at the outset of Indentureship, starting in the confines of the "coolie depot," the Emigration depot on the banks of the Hughli river (Calcutta) that guarded/ warehoused new recruits before the voyage outward, ${ }^{13}$ then later in the confined space of ships. Colonial society viewed all Indians as simply "coolies,"14 but in reality, they came from diverse backgrounds. Thousands were Hindus of various castes (mostly agricultural or 'lower' castes) 
recruited from rural villages in the United Provinces (now Uttar Pradesh) and Bihar; Muslims were also recruited from northern India (Mangru, El Dorado 14). Madrassi Indians (considered a different "race" by colonisers) were recruited to a lesser extent from coastal villages in what is now Tamil Nadu (Mangru, El Dorado 14). Through the struggle for communication and survival, such differences became less important than points of affiliation out of which new communal bonds developed. Gradually, through blended tongues (e.g. Urdu, Hindi, Bhojpuri, Tamil, Telegu), and the blurring of regional, colour, caste and religious differences on the long journey

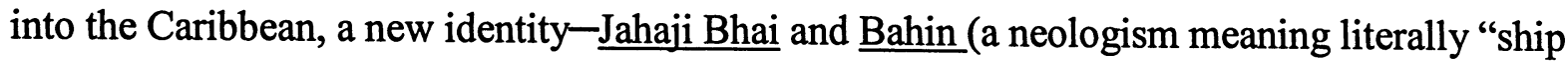
brothers and sisters")-seemingly more suited to the realities of their destination appeared (Simpson "Responding). Later in the confined quarters of the logies (their new homes on the plantations) they continued to forge bonds of Jahaji, sustaining mutual support and attachments created out of the common experience of the outward journey. In other words, a new, shared Indo-Caribbean culture was developing out of the physical conditions of Indentureship. ${ }^{15}$ And, as Mishra emphasises, the ship was the site of legitimation of this new identity ("Diasporic Imaginary" 429).

$\underline{\text { Jahaji bonds built on a diffuse "Indian-ness" also marked the place of indentured }}$ labourers in a society stratified by British colonialism and Plantation. Even though class, caste, colour and religious distinctions were not obliterated, travel from India for destinations unimaginable made identification with a singular "India" more feasible than previous markers of identity and belonging; being "Indian" was partly a continuation of ancestral lines, but also a response to a new society and place in that society (Simpson "Responding"). Identity markers in this new society based on gradations of skin colour (from light to dark) and European values (e.g. with Christianity and Standard English at the top) placed Indians towards the bottom of the 
hierarchy. As Jagan recalls, “The Indians, although 'brown' in colour, were not accommodated within the social hierarchy. They were regarded as outcasts and despised by the creole society as 'coolies,' as being culturally different and economically subservient" (Jagan qtd. in Ramharack 34). However, bonds of Jahaji as an expression of group solidarity were also a symbol of resistance to the divisiveness of colonial domination that relentlessly splintered communities (A. Khan 132).

"Divide and rule" strategies were a long-standing means to maintain colonial order. Lamming locates the seeds of racial conflict (mainly between Afro-Guyanese and IndoGuyanese) in Guyana within planter tactics that used bound labour for unpleasant and timesensitive tasks ${ }^{16}$ therefore depressing the wages of hired labour (e.g. Afro-Guianese) (xxii). ${ }^{17}$ Additionally, under terms of Indentureship, Indians were allowed to maintain names, language and culture, unlike the case with Africans under the system of Slavery. From a diasporic perspective, language use is an important marker of either community belonging or separate identity. Facility in an Indian language was an important connector to India, making communal ties possible through imported music and films (Simpson). While this enabled Indians to maintain religious and ethnic links, it also led to concerns that Indians were caught between two worlds-i.e., inassimilable outsiders. The option to return to the Motherland was one form of escape from this perpetual outsider status (Tinker, Banyan 50). Otherwise, if one settled in the Caribbean, one could not fully belong without losing outward signs of Indian identity (Espinet 102).

In the post-Indentureship period (i.e. 1917 onwards), when the perception of Indian was no longer formally tied to labourer and Creole (i.e., someone born in Guiana) described the majority of the population, self-conception among the ex-indentured population was becoming 
more creolised. Caribbean creolisation was not a top-down process of assimilation into dominant norms; rather, it was an interactive, albeit ambivalent process of mixing and merging (E. Brathwaite 6). Rodney considered creolisation an indigenisation process (178). The brutal manner in which African slaves were forcibly dislocated to Caribbean plantations, meant that for Africans, family and physical ties to Mother Africa were destroyed. The process of creolisation, however was a means claiming space in the Caribbean, and an Afro-Caribbean Creole culture came to characterise the region. An indigenising process through creolisation was also evident in both an Indian-influenced culture found in Guiana and the adoption of local customs by Indians (178). Indeed, cultures were not blocked off from each other (Gilroy 51). Inter-faith marriages were common, and relationships between African and Indians were not unusual. Creole patois was quickly replacing Hindi as the language most frequently spoken by Indo-Caribbeans (Tinker, Banyan 13). In addition to speech, creolisation was apparent in customs of food, dress, and funeral rites (Rodney 178). Paradoxically, however, the indigenising potential of creolisation led to competing claims among Indo- and Afro-Caribbeans (E. Brathwaite 54).

Negotiation for "authentic" belonging between these subordinated groups stemmed from the divides within Plantation society. A dichotomy was created between "natives" i.e. AfroGuianese and the "immigrant" or Indo-Guianese population (Rodney 183). For instance, few occasions for mutual interactions existed. Circumscription to the sugar estates excluded progressive or socially mobile opportunities for Indians, and also created disconnections between Indians and the broader Caribbean society (Simpson). The Indentureship system, while transcending differences among indentured labourers, served to reinforce differences between Irdians and other populations. As a result, Indians were often seen as a "recalcitrant minority"18. who lived apart, were culturally different, or even inferior (i.e. "uncivilised," in terms of culture, 
religion, language, dress, literacy, education, political participation and economics).

Furthermore, Tinker views the recruitment selection of indentured men over women as skewing normal patterns of marriage, and the subsequent development of second and third generation Indo-Guianese who would identify as Caribbean (Banyan 5). The shortage of indentured women sometimes resulted in polyandry, and jealousy was common (Tinker, New System 204). As a result, stereotypes emerged that hindered integration. Indian men were perceived as "wifekillers" and Indian women as "wanton" (Ramdin 199). Delayed claims of full Caribbean belonging, then, were mostly attributable to the dynamics of colonialism and Indentureship. However, Puri distills the roots of "out-group" status and questions of Indian belonging to the Caribbean down to the right of return clause in indenture contracts (171). Indians were temporary workers with a right to leave, not individuals with roots in the Caribbean (although transient British or North American plantation managers were never seen along the same lines). Furthermore, the right of return was challenged by plantation owners who viewed it as a loss of acclimatised labour, mocked in calypsos ${ }^{19}$ and discounted in newspapers. ${ }^{20}$ Yet, the constant departure of return ships indicated the lure of the Motherland despite criticisms (Dev vii-viii). The degree to which return was realistic was questionable since diasporisation irreversibly changed individuals, but the power the right of return held in the imaginations of indentured labourers meant that at one point every indentured Indian labourer who came to British Guiana had to confront the question: where is home (if any where at all)?

Stuart Hall's characterisation of diasporic identity along two possible lines as 1) a fixed identity with a reference point, such as home/origins (for example, the type of collective identity called upon in national liberation struggles), and 2) an identity "in flux" (in which the struggle to reclaim roots is part of the trauma of colonialism), undergirds this paper (234-236). Hall posits 
that Caribbean identities are a dialogue between these two vectors, one placed historically and the subsequent a reminder of "who we have become" since the discontinuities and ruptures of the past (236). These identities are not mutually exclusive; difference can co-exist alongside a rooted identity (Hall 238). Hall also makes the point that all return journeys are necessarily circular; one never returns to an original point unchanged by the journey (242). This is helpful to disrupting a linear understanding of return journeys, and rather frames return as search for wholeness. As Mishra (speaking of his own self-identified community of the old Indian diaspora) states, "Selfreflection begins with the need to address where we came from and where we are headed, for without exploring these questions, we cannot face up to our own ghosts, our own traumas, our own memories" (“Impossible Mourning" 28).

Gilroy also lays important groundwork for understanding Caribbean diasporic history. In the "Black Atlantic," he argues the ocean is an important unit of analysis to understand both the roots of history and the routes of journeys (62). The "roots" may represent a homeland in which one ought to belong (Gilroy qtd. in Mishra, "Bordering Naipaul" 195), and oceans signify the "routes" not only of the transcultural movement of people, but a literal and metaphorical space in-between two worlds (64). In examining return journeys, the symbolic power of shifting ocean waves argues against a simple linear analysis of return movements, instead suggesting fluidity between and within nations that call centre(s) (i.e., homeland/ national origins) into question (64). The very nature of oceans reinforces the notion of fluid identities. Although Gilroy and Hall are speaking to an African diasporic context, the significance of the ocean is also relevant to Indo-Caribbeans as the very history of Indians in the Caribbean -Indentureship-was the cause of their ocean crossings for over a century, ending with the voyage of the M.V. Resurgent. 
Without such a nuanced understanding of Caribbean identity, the reverberations of the Indian sub-continent would be lost, if not for diasporic space. Echoing Gilroy's "Black Atlantic," Mehta uses the term "Kala Pani discourse" to stress the historical dislocations and cultural displacements specific to the Indo-Caribbean diaspora (7). Crossing the Kala Pani is a metaphor for transition from "old world" to "new," and the accompanying transformation and creolisation that resulted in an Indo-Caribbean identity (A. Khan 123). Mishra suggests that concepts such as

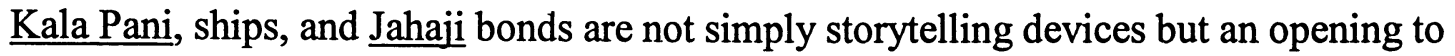
interrogate previous understandings of the Indo-Caribbean experience ("Bordering Naipaul" 196). By stressing the opportunities that a boundless ocean presents to set identities adrift or to transform identities through transoceanic dialogue between fixed points, Mishra, Mehta and Gilroy each conveys that the Caribbean diaspora is a shifting construct, reformulated in various ways under different historical exigencies, as later chapters will illustrate.

This section demonstrates that Indian indentured labourers were systemically marginalised under systems of colonialism, plantocracy and Indentureship, and culturally marginalised due to "coolie" and plantation traumas. Evidence of their marginalisation was seen in questions of their belonging to the Caribbean. Furthermore, this chapter focuses on diasporic themes related to return-ships and ocean journeys-as significant markers of diasporic identity, and outlines the importance of return as a concept in the initial outward journey, as a sign of hope or yearning in the face of trauma, as a colonial procedure, and as an example of agency under oppressive conditions.

The concept of return was used as both a moment of leaving (action) and a hope (embedded in the collective psyche), as well as an important means of exploring relations to homeland (India). Ships are relevant to return accordingly: 1) as physical space containing 
trauma; 2) as a site of identity transformation; and 3) as a moving concept to highlight links and breaks with points across the Atlantic. These metaphors are linked to trauma, belonging (in relation to homeland), and return, and illustrate inherent aspects of an Indo-Caribbean narrative. The historical and diasporic importance of return ships set out a context in which to understand the voyage of the last return ship, the M.V. Resurgent. 


\section{CHAPTER 2: RETURN JOURNEY}

"[Y]ou ain't go learn all that in History book. Listen good so you will know what you come from.” (I. Khan 25)

The premise of this section is that a broadly conceived "diasporic archives" ${ }^{21}$ is needed to understand the last repatriation. The main substance of this diasporic archive is the oral history of Ramcharan (the last Repatriation Officer), interwoven with archival sources to retrieve a fuller picture of the last return of 1955 . It is difficult to separate history from memory as they are both subjective and subject to revisions; thus, to foster an understanding of the tangled connections of memory, history and diaspora, it is necessary to briefly outline how the forces of memory, literature and the archives cumulatively give shape to history. Although return movements related to Indentureship comprise a relatively recent and documented history, the meaning of archival records is notably expanded with the inclusion of emotional and imaginative information in addition to "factual" data (A. Khan 123).

\section{Chhablal Ramcharan}

Ramcharan's high score on the Hindi interpreter exam gained him an entry-level position in British Guiana's civil service. In those days, the colonial government did not encourage statefunded Indian education and, as a result, Indians were largely excluded from gaining positions within the country's bureaucracy (Mishra, "Bordering Naipaul" 215). Most lower to middle class boys in the Caribbean strove to enter the civil service, as it symbolised a significant step away from the harshness of Plantation life (Clarke 6). However, it was not an easy journey from the canefields to the government offices for members of the Indo-Guianese population. Indians holding positions such as interpreters in the Immigration Office, and (male) nurses on the 
indenture/ships were exceptions and it was these early trailblazers who formed the beginnings of an Indo-Caribbean professional class (Rodney 112).

Ramcharan's civil service career with the Immigration Office began in 1944. He held the position of Interpreter-Clerk, and as Interpreter/ Immigration clerk he performed myriad roles. At that time, an Interpreter/Immigration clerk was involved in matters that ranged from dispute mediation in labour issues to conflict resolution in domestic affairs among Indians. Ramcharan stated: "Our work was both social and immigration, looking into the welfare of immigrants" (Ramcharan).

The self-acknowledged highlight of Ramcharan's career was his appointment as Repatriation Officer which meant that he would accompany the final group of returning exindentured labourers onboard the M.V. Resurgent in 1955. His role on the ship was administrative, and he was expected to carry out the procedures of return as specified under the Indian Emigration Act as well as to look after the general welfare of passengers (Ramesar 190). At the time, it was customary to appoint the Senior Immigration Officer as Repatriation Officer, but the Immigration Agent General (D.L.B. Wickham) appointed Ramcharan due to his fluency in Hindi (Mohabir and Simpson 500). Years later, after completing his stint in the Immigration Office, Ramcharan became Superintendent Registrar of the Georgetown district, and later retired from public service as Personnel Manager in the Ministry of Housing and Reconstruction. ${ }^{22}$ In addition, until his departure from Guyana in 1975, he was the voice of the Arya Samaj (a reform Hindu movement), which broadcast early morning prayers on Radio Demerara that were heard throughout the West Indies.

Ramcharan immigrated to Canada following a grievous assault in Georgetown. In the unanticipated permanency of the move, personal belongings, such as letters, photos, and 
mementos were left behind; what remained of his past and his involvement in Guyanese history resided mainly in his memory. In a series of conversations over the summer of 2005 , he proceeded to recall the last repatriation with ease, as if the details of events fifty years prior had crystallised in his mind.

\section{Memory, History and Communal Identity}

For communities "on the move," the memories of elders are inextricably linked to their sense of history; it is in the voices of elders that the past is given shape and substance. The challenge is to hear the lived reality in those voices while simultaneously understanding the shaping of that reality by dominant systems that caused the moves, such as capitalism, (neo-) colonialism and Empire (Dossa 22). First hand accounts rooted in memory, such as Ramcharan's, can illuminate past events in a way that history texts simply cannot. As Brodber states, by "tapping [into] the memories of grandfathers ... to make visible formerly 'invisible history' the oral historian enter[s] the minds and hearts of the ancestors" $(5 ; 2)$. Further, Gopie calls out to second generation Indo-Caribbean Canadians to know where they have been and where they are going by recording the "cultural road maps" and "psychic sign posts" of the community (65).

For subsequent generations of Indo-Caribbeans, especially those born abroad, Gopie's challenge requires reflection. Who (was and) is (becoming) Indo-Caribbean? Where is (will be) home for an Indo-Caribbean diaspora? What are the signs along the way? Identities are not fixed, and past contexts do not always have the power to shape a people's sense of themselves. Embedded in intergenerational conversations are the questions of "who are we?" and "who are we becoming?" (Hall 236). Responses to these questions are found in moments of intergenerational exchange that bridge time and distance to foster a collective identity. In 
particular, distance from home, and the invisibility of Indo-Caribbeans in places such as Canada (where the Caribbean is perceived as solely an Afro-Caribbean space, and Indian interpreted to mean only South Asian) creates a situation where family and elders become the main source of knowledge about cultural identity (Natarajan xviii).

Intergenerational conversations then are more than personal; they are a bridge between the personal and the communal, between the private and the public. A key question posed by Mishra-"First of all to whom [does one] recount [the story]? (Impossible Mourning 32)"suggests stories must have a home, a "community of listeners" who accept, and carry on the story (Dossa 22). However, this does not confer automatic acceptance of oral (and written) stories or collective memories; memories can challenge community especially when the potential to uncover "ghosts" exists (Hua 198). Ramcharan's story, told over the next two chapters, demonstrates the evocative power of memory to both fill in the gaps in officially documented history and reveal secrets of a community's past.

Oral history can reveal the incompleteness of official narratives of the past and can also function as a strategy to recall suppressed stories (Hua 198). Events may fade from diasporic memory for several reasons. Dominant society's emphasis on histories that glorify the state can lead to alienation from the lived experience of history (Brodber 2). Secondly, the stress of Western education on "book-learning" means that marginalised people often inherit a history which does not include or validate them (Brodber 2). And, in some cases, colonial domination was also internalised-that colonised peoples' themselves often felt their own stories were not worth knowing. As Naipaul puts it in The Middle Passage, "We could never be convinced of the value of reading the history of a place which was, as everyone said, only a dot on the map of the world" (42). Specifically, for indentured Indians, collective amnesia-"the cultivation of 
forgetfulness"-was necessary to start over and build a life in the Caribbean (Seecharan, "IndoCaribbean People" 64). Traumatic rifts were necessarily forgotten in order to adjust to the new environment.

However, absences are revealing. Even in Guyana, the last return journey had disappeared from living memory (Mohabir and Simpson 488), but the act of retrieving history can permit subsequent generations their own route to understanding the concept of "we" in "who we are" collectively (Ahmed 78). As a substantial body of pioneering scholarship on the IndoCaribbean diasporic experience exists, Caribbean culture can more than withstand "root" searching (Harvey 97). Moreover, traumas can only be healed when connections are once more set in place $^{23}$ (Hall 236).

Few have made historical claims about the voyage of the M.V. Resurgent. Scholarship on Caribbean history provides documentation on the existence of the ship and facts of the journey (e.g., number of returnees and remittances) (Nath 75; Laurence 539), but offers little analysis of personal experiences or the surrounding context. Most essays on return passage do not include discussion of twentieth century return ships (for example: Mangru, El Dorado 51-65; Ramdin 152-156; Laurence 362-383). An exception is Ramesar's direct account of an early twentiethcentury return voyage from the perspective of an Irish-Trinidadian (Linton Gibbon, son of Trinidad's Senior Inspector of Immigrants at the time). Gibbon viewed return passage as "a gift," not a right; his narrative does not give insight into the Indo-Caribbean psyche or the views that Indo-Caribbeans had about pulling up roots again and going back to India. Others appear to have forgotten about the voyage of the M.V. Resurgent. For example, Shepherd cites the last Caribbean return journey as occurring in the 1940 s, as does Laurence ${ }^{24}$ (Shepherd, "Poverty" 102; Laurence 381). Birbalsingh was the first to record Ramcharan's experiences as the last 
Repatriation Officer in From Pillar to Post (65-74), but as one of a series of life interviews, there was little discussion of the significance of the journey. Only Tinker provides an analysis of the last return; he contends (but only in the space of one sentence) that Guiana's anti-colonial struggles were a factor in the M.V. Resurgent's voyage (Banyan 68).

Many scholars agree that accounts of repatriation are one of the least studied aspects of Indian/Indo-Caribbean diaspora (Singh 298; Tinker, Banyan 138; Ramesar 175; Jayaram 23). ${ }^{25}$ The focus of much of Indo-Caribbean scholarship has been on their arrival and settlement in the Caribbean, in recognition of the complex marginality which has erased their history in countries or regions where they have lived for over four generations. In addition, an absence of recorded history among Indo-Caribbean people has detracted from the task of getting a better understanding of their lived experiences (Seecharan, "Indo-Caribbean People" 64), especially in regard to their orientation to the Motherland (India) (Jayaram 31). As Naipaul comments, "There is an ignorance of the Indian community [in the Caribbean] not only from without, but also from within...[w]e forget, we have no idea of our past; it is part of the trouble (qtd. in Ramdin $\mathrm{x}$ ).

\section{Literature and History}

Literature and history have much in common, as both invent narratives (Hubel 4). But literature can reveal what "pure" history cannot-through imaginatively reconstructing the emotional and psychological dimensions of past events and breathing life back into those who had lived through them. In contrast to facts and figures, stories can help locate sorrow or loss in the collective psyche, such as the loss of family or homeland. Story-telling can build community and be a tool to exercise agency, helping members of the community to remain mindful of events of "long time" (Ganz 3). Given the dearth of information about the personal experiences of indentured labourers, the only way to understand their lived experience is through tapping 
memory, recovering oral history or reading literary reconstruction. As Taylor notes, meaningful narrative reveals the dynamic of experiences, practices of resistance and hopes for the future (xii). To that end, this paper employs excerpts from literature, intertwined with the oral historical account of Ramcharan to provide insight into the Indo-Caribbean experience.

\section{Archives and History}

Many scholars have relied on official archival documents to reconstruct Indentureship history: emigration passes; correspondences between the Protector of Immigrants/ Emigrants and the Governor or Colonial Secretary or between the Colonial Office and the India Office; newspaper accounts; and ships' lists (Shepherd, "Poverty" 93). In these records the ghosts of colonial domination live on; however, in these documents are also found, as Mishra points out, the beginnings of indentured labourers as historical subjects ("Diasporic Imaginary" 429) as the archives document their journeys out of rural Indian villages into official history with specifics, such as their names, bodily marks, scars, and caste. Still, such information cannot breathe life into their stories or give us a sense of their longings and losses, their hopes and their dreams.

Though archival materials provide details, relying solely on the archives would present a singularly top-down perspective. Thus the "diasporic archive" under consideration consists of oral history, ancestral consciousness, literature, and memory, as well as information available in the archives to reveal "a people's history from their own perspective rather than from others who claim to speak for them" (Shepherd, "Poverty" 94). This version of the archive, while not containing the whole story, is evocative of a meeting point between inner memories and external history, and embodies shared decisions made as a society to either retain or forget information, making evident the interconnections and tensions between past and present (Sheringham qtd. in Mohabir and Simpson 490). As Simpson notes, the "archive" understood broadly, can 
"accommodate both already existing documentation and oral 'documents'...that are in the process of being made and in the process of entering into the body of existing knowledge." (Simpson).

\section{Return Narratives: Literature}

Few novelists actually portray Indo-Caribbean characters who are seriously contemplating a permanent return to India (Ramraj 77). As Ramraj notes, writings of major IndoCaribbean authors such as Naipaul, Selvon, or Bissoondath contain only a few minor characters who dream of India but are hesitant to return (although in his non-fiction works Naipaul writes more expressly about return) (77).

One of the few Caribbean novels to explore an explicit longing for India after that country's liberation from the British is The Jumbie Bird by Ismith Khan. At the core of the novel is the character of Kale Khan, a grandfather, respected community elder, and fierce Pathan warrior caught in a moment of fluctuation as the Empire begins to dissolve. Though Khan is a "free" migrant ${ }^{26}$ to Trinidad, he is concerned with the number of men set adrift after their indenture contracts expired, wandering around the town square: "their eyes filled with a strange yearning and discontent" (28); men whose labour "made other people rich" yet never made enough money themselves to cover the subsidised passage home (179). ${ }^{27}$

Khan is the figure that links India's liberation to a story of resistance in the Caribbean: "Kale Khan sat at his counter writing another letter to Hindustan. He expressed his joy over the freedom of India, pleading for help in the repatriation of his people. In his letter he continually told of the injustices to Indians in Trinidad" (165). Khan fueled his island-wide campaign for mass repatriation by reading in the Public Library all the "reports of punishments, reprisals, fines, legislations, which bound his people to the Island, laws which suppressed the learning of 
their own language, the passing of their own culture and tradition, their festivals" (180). In his advocacy efforts, Khan links Indentureship traumas to the struggle to be free of colonial rule. For him, India represented an escape from an oppressive existence, as well as a place to belong. For the dispossessed elders depicted in the square, India symbolises a hope for possible economic security, as well as the site where their fragmented existence could possibly be made whole.

The novel culminates with the Indian Commissioner's visit to Trinidad, shortly after India's independence. After independence, India sent quasi-diplomatic representatives to the West Indies, stirring local pride, but also creating fears of a "Greater India" among non-Indians - (Tinker, Banyan 60). Khan is hopeful that his dreams of mass repatriation will be fulfilled, but instead the Commissioner was sent to cut official ties with Indo-Trinidadians. The Commissioner states bluntly that Trinidad (not India) was now Khan's home. Soon after this, Khan dies, as does his dream to return, leaving his grandson crying, "Dada...Dada...You gone to sleep, and who will take us back to Hindustan? Who?" (175). The novel ends on the question of home raised by decolonisation, and suggests the impossibility of returning to India.

It is interesting to note that Kale Khan and his family are Muslims who are dreaming of returning to "Hindustan." As noted in the previous chapter, there are significant historical differences between the old and new Indian diaspora. For one, the homeland of the older diaspora is a singular sub-continental nation comprised of both Muslims and Hindus, as distinct from the multiple homelands of South Asia created after India's Partition (e.g. the predominantly Muslim countries of Pakistan and Bangladesh, and secular India). "Motherland" for IndoCaribbeans, whether Hindu or Muslim, referred to a collective India prior to the religious divides and dismemberment of Partition. The memory of India held by Indo-Caribbean elders like Khan (whether Muslim or Hindu) embodied a desire to be re-united with the centre, like "a limb 
remembering the body from which it has been severed" (Walcott qtd. in A. Khan 65). This understanding of original homeland led many Indo-Caribbeans to view Indian independence as a victory for all Indians; however in actuality it was a movement torn apart by ancient affiliations (Simpson "Responding").

Selvon offers an observer perspective of repatriation in An Island is a World (first published in 1955). This novel took place within a post-World War II Trinidadian society that queried a Caribbean person's place in the world. Over the course of the novel, characters seem rootless, placeless. Sugar cane is no longer a "green prison" 28 that holds them to Trinidad; Indians are no longer bound to the land. However, as migration opportunities open, the main character finds the world spinning in his brain (1). During the mid-twentieth century, early Caribbean migrations outward to England or America were occurring, at the same time as the last journey back to Mother India (Ramchand viii-ix).

Ramchand notes that the creolised Indo-Caribbean protagonist in the novel (Foster) "understands their [repatriates'] anxiety to have something to belong to" (viii):

Foster looked about him, a strange emotion in his heart. He was one of them [Indian in the Caribbean], and yet he couldn't feel the way they did, nor share in the kinship they knew. They were going back home. They had a home. It was far away, but they hadn't forgotten. When they had come to Trinidad they kept some of India hidden in their hearts. ...They had something to return to, they had a country (Selvon, Island 211). Although by this time multiple centres of home were emerging, for some the emotional pull of home was still defined territorially by India; for others home was shifting, rooted in the Caribbean and beyond. 


\section{Return Narratives: Contested}

Opinions of indentured labourers were excluded from debates on repatriation (Ramdin 155), and any personal testimony that would give explicit insight into the feelings, emotions or yearning for return is rare. However in interviews with surviving ex-indentured labourers in Trinidad (recorded in creolised "coolie" English) Mahabir captured a sense of loss embedded in the unfulfilled desire to return:

"we di want to go back india

but which part e go go back

which ship

an who go gi we de ship" (Fazal qtd. in Mahabir 60).

The question of "who will give us the ship" is significant, because unlike Guiana, Trinidad did not grant requests for repatriation after India's independence. Furthermore, the interviews also portray the hope that return offered to escape a subservient existence on the plantations:

"if ah see india ha rich man ...

India ha million ah million rich man ...

in chinedad every man living barrick" (Bharath qtd. in Mahabir 104).

"I din have money to go India

you tink I eh like it

I born over dey

an I come big

but over dey wuk nuh hard

hyar wuk more hard 
over dey wuk no hard

an no driver

no bossiere behind you" (Sankar qtd. in Mahabir 179).

However, among the elites of Indo-Caribbean society, those who gained higher education, moved away from plantations and established themselves in urban areas, the desire to return was viewed as detrimental to the colony. In one of the rare existing primary source documents, the Centenary Celebration of the Arrival of Indians to British Guiana-originally published in 1938 by the British Guiana East Indian Association (BGEIA), a group of middle class Indo-Caribbeans who perhaps saw themselves as "protectors"-space was dedicated to ending repatriation. They derided the impulse to return as a "follow-the-crowd instinct" and lamented the potential loss of "man-power of the country so sorely needed for further economic development" (Ramlogan 32-33). Instead, they proposed a measure to discourage repatriation by using the colony's Immigration Fund ${ }^{29}$ to grant land to ex-indentured labourers (Ramlogan 3233). This debate was ongoing in 1955, when Indo-Guianese Member of the Legislative Council, Sugrim Singh called repatriation a waste of public funds; he too advocated for land settlement ("Back to India Waste").

Indentured labourers may have had the right to return, but they had no "right" to land. Colonial documents bemoan the cost of land settlement. By the mid-1950s, the Indian government held the view that repatriation should be offset by an inducement from British Guiana to remain in the colony. However, the colony felt that those who had no desire to return would gladly surrender return passage to gain land. Besides, land settlement was a contentious issue for all segments of Guianese society (Guyana "Letter"); especially for former slaves and their descendants who were not only denied land grants but who were forced to overcome sizable 
obstacles (inflated prices, legislated barriers, plantocracy fears of competition) to purchase land (Rodney 60-80) . Moreover, many within the broader Indian community viewed relinquishing return passage as giving up a fundamental right and actively resisted these initiatives-or at least advocated for a sizable land grant (Rodney 183).

\section{The Role of the Immigration Office}

The Immigration Agent General headed the Immigration office; his role was to protect the indentured labourers' welfare and ensure plantations met statutory requirements (Mangru Benevolent 166; Nath 50). The Immigration Office inspected plantations and hospitals, dealt with wages, mediated disputes between indentured labourers and employers, and translated documents (Nath 153; Ramcharan). ${ }^{30}$ Functions also included monitoring the arrival and departure of ships to and from India, and determining whether regulations were observed on board (Nath 50). As noted previously, return journeys took place with regularity for over a century, with indentured labourers going as they had come: in ships. As numbers warranted, a ship would be chartered for those claiming their right to return. Across the British Caribbean, respective Immigration Offices were charged with carrying out the procedures of return (health inspection; checking documents; ensuring adequate ship supplies for the journey; and distributing remittances) (Ramesar 189-190; Laurence 366; Ramcharan).

An indentured labourer remained under the protection of the Immigration Office not only during his or her term of indenture, but until the time he or she claimed return passage and left the colony (Nath 152). Having a dedicated custodian in the form of the Immigration AgentGeneral and his counterpart, the Protector of Emigrants of Calcutta, underscored the paternal relationship of colonial authority to Indians. In fact, as Tinker observes, the British Empire was run by such paternalistic, authoritarian men (New System 148). The expectation that the 
Immigration Agent-General's Office would protect Indians had a long history in Guiana, stemming from the days of Immigrant Agent-General James Crosby (1858-1880), who battled planters and the governor in his efforts to recognise the rights of Indian indentured labours (Nath 48). In his memory, indentured labourers extended his name to Immigration Office staff (including Ramcharan), referring to them as "Crosby Baboo" (Mohabir and Simpson 500).

An office with a reputation for protecting the rights of Indians, but defined ostensibly along ethnic lines, delayed a sense of belonging to British Guiana among indentured labourers. As Seecharan notes, there was a persistent sense that Mother India (or perhaps more fittingly "Father India") would protect Indians in Guiana (Seecharan, Indo-Guyanese 55). Although the office was needed due to the overwhelming control the planters had over the.lives of cane cutters, the long-term repercussions were felt in a prolonged ambivalence among indentureds towards embracing Caribbean-ness and also delayed their being recognised as belonging to the Caribbean by others (Seecharan, Indo-Guyanese 54$)$.

Even though safeguards for the welfare and right of return were crucial for indentured labourers, legislated obligations were conceived mainly in the interests of the planter class to facilitate a recruitment and supply of cheap labour. It is for this reason, that the Canadian missionary, Reverend John Morton, supported the absence of time limits on return claims as he felt that a pressure to claim return passage within a specified period would diminish subordinate labour in the colonies. However, without any time pressure, "immigrants" would simply drift along, eventually becoming entrenched in the country (e.g. raising families) and would no longer desire return (Ramesar 196). Although a policy that unmoored indentured labourers was strategic for most of the history of Indentureship, policy-makers did not foresee the considerable interest in return passages following India's liberation. 


\section{Indian Independence and the Last Return}

At first glance, demand for a mid-twentieth century return ship appears surprising. The M.V. Resurgent set sail in 1955, some four decades after the last indenture/ship brought Indians to the colony (Ramcharan; Guyana Register). As early as 1880, unindentured Indo-Guianese residents already outnumbered indentured Indians on plantations (Rodney 34). By 1955, Indians had become the majority ethnic population in Guiana, with 230,860 Indo-Guianese ( $47 \%$ of the population) recorded in that year's census (Nath 235). Although the final number of individuals who opted for return was small, the significance of the journey lies in its symbolic representation.

Ramcharan links the timing of the last return journey to the ripple effect of India's independence. India's independence produced waves of reaction throughout the Caribbean. IndoCaribbeans were inspired by India's political liberation: many wore saris, raised the Indian flag, and celebrated with calls of "Bande Mataram" ("Hail to the Motherland") (Ramcharan). Trinidadian politician Albert Gomes recalls the response to India's independence (as well as reveals the disapproving attitudes of the elites):

Gandhi hats and sumptuous saris suddenly reinforced the exotic and richly varied landscape. It was as if a cult had exploded in our midst and was casting its incongruous abracadabra everywhere...India's patriotic holidays were observed in Trinidad with a fierce jingoistic zeal by the descendants of the immigrants who had originally come as indentured labourers for the sugar estates. The process of assimilation was reversed. (qtd. in A. Khan 11).

Although India's political achievement had an emotional resonance with both ex-indentured and Creole Indians, the majority were not actively involved in a "Back to India" movement. In fact, 
Singh queries the use of the term "Back to India" movement, as it was a loosely organised and relatively unstructured grouping (298). People may have "continually talked of going back to India, but when the opportunity came, many refused, afraid of the unknown, afraid to leave the familiar temporariness" (Naipaul qtd. in Mishra, "Impossible Mourning 45).

For those who felt the call (the "hard-hatted" ones as Ramcharan called them), a movement for repatriation, similar to Kale Khan's organising efforts in the Jumbie Bird, arose. In 1947, the year of Indian independence, hundreds of Indians in Jamaica organised "Back to India" demonstrations (Parekh 10). In Trinidad, India's independence provoked ex- indentured labourers to threaten group suicide, if not repatriated (Selvon, "Three" 6; Parekh 9). In Guiana, Gandhi's fight against colonialism inspired immense pride (Seecharan, "Indo-Caribbean People" 73). Indian national struggles received abundant attention in the media, and editorials speculated on the implications for Indo-Guianese (Seecharan, Indo-Guyanese 37). India remained a source of inspiration for Indo-Guianese regardless of whether they felt their future lay in India or Guyana. Nevertheless, mass repatriation was probably a "desperate, limp threat;" yet it illustrated the extent to which a freed India had sparked the Indo-Guianese imagination (Seecharan, Indo-Guyanese 59).

This unique political moment is important because, as hooks asserts, decolonisation calls into question "the very meaning of home" (148). Singh suggests that most twentieth century Indo-Trinidadian demands for repatriation were linked primarily to dire economic factors in the colony (300). Therefore, the particular circumstances of India's liberation and accompanying hopes for freedom or nationalist belonging sets the M.V. Resurgent apart from most of its predecessors (with the exception of the Orna). Selvon wryly observes that many Indo-Caribbeans suddenly remembered they were Indian with India's independence, suggesting the awakening of 
a latent affiliation in the form of patriotism (Island 161). Similarly, Ramcharan affirms many Indo-Caribbeans began referring to India as "we mother country" and launched a letter writing campaign, as well as made representations to the colonial secretary, the governor and other colonial officials to advocate for a return ship. A greater number of individuals participated in these efforts than those who actually left (Ramcharan). Years of struggle against plantation management strengthened collective ties, almost certainly leading many to support their Jahaji Bhai and Bahin who desired return.

To agitate for the right to leave the colony of Guiana to return to a decolonised India was -undoubtedly an anti-colonial act, albeit under the controlled conditions of return passage regulations. Even so, desire to return was not a form of romantic resistance. Up until the midtwentieth century, the white plantocracy remained dominant (Tinker, Banyan 54). However, counter to "being shunted here and there" to meet the needs of planters, "people were saying: the white man bring us here [Guiana], they got to send us back" (Mohabir and Simpson 502). Similar remembrances are found in the literature. In an Island is a World, Selvon notes the impetus behind "Back to India" organising efforts: "We must stand up for we rights" (163).

Selvon further contextualised "Back to India" agitation as a form of nationalism within the historical period of emerging nation-states, writing that the world is made up of nations; one cannot belong to the world (e.g. be a cosmopolitan citizen) "because the world won't have you;" one must belong to a nation (Island 106). Thus, the desire to belong to the new Indian nationstate had multiple meanings. It could be viewed as an expression of collective resistance, or a more practical response to unfolding political exigencies.

Responding to mounting pressure, the Guianese government chartered a return ship (Ramcharan; Guyana Executive Council April).Usually, countries with ex-indentured labourers 
would share the costs of chartering a return ship, as in later years a single country would not have enough returnees to justify the cost of charter (Ramcharan). But in 1955, when requests to other colonies (i.e., Trinidad, Jamaica, Surinam) failed to produce a positive response, the Guianese government decided to support a return ship on its own (Ramcharan; Guyana Executive Council February).The Guianese government was under an obligation to fulfill the right of return, and felt significant demand warranted chartering the M.V. Resurgent (interestingly, the name of the ship reflected the resurgence of pride that initiated its charter) (Ramcharan). Stating that this would be the last ever return vessel, the government anticipated at one point that up to a thousand would register for return (Ramcharan). But Seecharan was correct in his characterisation of repatriation as a limp threat. Initially only a third, then dropping to a quarter, of that number registered to return ("300"; 250 Repatriates"). First-person accounts suggest that in the end, too much time had passed (Ramcharan). Most people though inspired by India's liberation, had raised children and grandchildren in the Caribbean and laid down their roots (Maharani qtd. in Mahabir 88). ${ }^{31}$

Many of the returnees were older—over fifty years of age (Guyana Register)-and some were heeding an "end of life" calling to return to the homeland:

And now in the seventh and

final stage

With bending backs and weak old age

This land you built, you leave this day. Your bones in Bharat Desh 
to lay (Dwarka 43).

Cremation (an important funeral rite under Hindu customs) was not legalised until 1954, at which time "Back to India" representations were already underway, and the first cremation in Guiana did not occur until 1956, after the M.V. Resurgent's journey (Mohabir and Simpson 497). Ramcharan states that for some returning home to die was a motivating factor, and in the literature Selvon writes, "But nothing could quench the fire now. Men were dreaming about dying on the banks of the Ganges" (Island 163). Ramcharan recalled some made do with religious rituals held by Guiana's rivers and waters (Ramcharan), but although religious ceremonies were transplanted to Guiana, Guiana could not hold the same emotional resonance as the Motherland.

Others, as Ramcharan remembered, were inspired by Indian films shown throughout Guianese cinemas. The films portrayed an ideal India (not one of hardship, Partition or famine) and a life far removed from plantation realities (Tinker, Banyan 94). Ramcharan suggests that these images fostered a yearning to belong to the affluent imagined community portrayed. The term “imagined community" gained its existing popularity from Anderson's book, $\underline{\text { Imagined }}$ Communities, which describes the myths and practices used by nation-states to create an idea of common national identity and patriotism among disparate peoples. Anderson proposes that all communities are bound together by a shared conception of their history and traditions, ideals and values. This postulates that identity conceived in terms of an imagined community might have motivated Indo-Caribbeans/Indo-Guianese to see themselves as part of the nationalist struggle or to identity in some way with an idealised "Old World."

Ramcharan did not mention re-uniting with family overseas as a deciding factor to return; however, the possibility existed even as late as the 1950s. Samaroo recovered letters between a 
father who was indentured to Jamaica in 1912, and his son left behind in India. The letters were written in 1954, when they had reconnected after a long absence:

Whenever your letter comes I wish I had wings

And could fly away to see you.

Your destitute sister has no one and

I am looking after her

She has gone blind crying for you.

She now lives only with the hope of

seeing her brother's face.

And my mother after receiving your first letter

cried for ten days and died (44).

More than a hundred passengers onboard the M.V. Resurgent arrived in Guiana within the last years of indentureship (1912-1917), making family reconnections though distant still possible (Guyana Register).

Although the reasons for desiring return were as complex and individual as the passengers, Ramcharan characterised the overall basis for the 1955 voyage as sentimental (Mohabir and Simpson 497); it is an assessment repeated in a dispatch from the Office of the. High Commissioner for the United Kingdom in India (Guyana "Letter"), and again in the literature (Selvon, Island 210). Sentimental ties may be viewed as nostalgia for homeland, after all "who has not known...the nostalgia for lost origins?" (Hall 245). In this view, Indian nationalism displayed in the Caribbean could be a collective emotional claim on India. Alternatively, sentiment may describe an individual process of imagining connections (or reconciling tensions) between past and present selves (Sugiman 63). Regardless, sentiment is not 
isolated from history and memory (Sugiman 63). In fact, sentimental ties can be a form of resistance to the erasure or denial of the past. In other words, sentimentality can be a reassertion of belonging, or an attempt to minimise trauma or loss (Sugiman 64).

Thousands of people from across Guiana traveled to the wharf to witness the ship and celebrate its voyage ("250 Repatriates" 1 ; Ramcharan).The M.V. Resurgent was the most expensive $^{32}$ and modern of all indenture/ships fitted with diesel engines, weighing 9404 tons (gross). Ironically, it was still owned by the British East India Company ${ }^{33}$ ("Back to India Ship" 1). Contemporary reports infused the M.V. Resurgent's voyage with nostalgic notions, remarking on the name of the ship (literally "to rise again") and called the voyage "a touching chapter in the history of the Old World and New World" and described it as "a journey of hope more than faith" ("But 44" 1). Pictures on the day of departure show a dense crowd at the wharf, who had gathered to pay homage to the journey ("Indian Repatriates"). The Argosy described the day as "a sort of holiday"; feted with the "finey" and "big bottle," and "as the ship made its way to sea... thousands filled the air with lusty cheers and muffled sobs" ("Resurgent Leaves" 6). Even among those who did not return, the event commemorated ties to another country (other than Guiana). It became not necessarily a day of sadness, but an event that captured the communal imagination (Simpson).

Singh argues that the idea of return was mostly symbolic - a celebration of pride in India's achievements (290). But for some (even if a minority), it was much more; return ships offered actual hope of deliverance. Naipaul describes the departure of the second to last Trinidadian return ship (Laurence 540), the S.S. Ganges that sailed in 1932, as a frenzied rush among those who saw this as their "last chance to go home, to be released from Trinidad" 
(Finding 61). In a similar return journey in search of "salvation," Selvon depicts a quiet and unremarkable send-off: ${ }^{34}$

They [repatriates] came towards the city the night before the ship was due to sail, because they were afraid that it might go away and leave them behind.... And all of them had a light in their eyes, as if salvation had come at last. It was a moving sight, all these old Indians heading for the wharf in Port of Spain where the ship was tied up alongside. And yet no one was interested in watching them, no one in the island felt that this immigration was a big thing, that people were leaving the country in which they had worked their lives away, to go to distant India purely for sentimental reasons. ... No crowd gathered. ... (Island 210)

Although this is a fictionalised event, is this haunting image (disavowed from the Caribbean's past) behind Selvon's insistence that "the full story in all its detail is worthy of record?" $\mathrm{He}$ continues to describe their leave-taking of Trinidad, "In little groups of twos and threes they came out of the night, wanting to be there early, in case the ship sailed away and left them, though they well knew the date and time of sailing, but to them it was quite possible that such a thing could happen" (Island 211). The anxiety of being left without a home or without a place in the world is palpably described in Selvon's imaginative reconstruction.

According to Ramcharan's recollections and contemporaneous newspaper accounts, the M.V. Resurgent's tear-filled departure (in comparison to the stoic departure depicted in Selvon's fictional account), spoke to the difficult decision made by many Indo-Guianese to leave family and friends behind. An interesting anecdote in a local paper summarises the ambivalence of leaving. A seventy-two year old ex-indentured labourer named Sookhai living in Cornelia Ida, British Guiana for over a half century registered to return and boarded the M.V. Resurgent, 
presumably after going through the necessary checks and inspections of the Immigration Office, but then changed his mind. An hour before the gangplank was about to be pulled, the elderly man called out: "Massa...Nah me baaya!" [Sir, not me] and leapt off the ship (Ramcharan). The newspaper report explained he was a "son of the soil" (implying he was truly Guianese) and attributed his decision to stay to family ties. As Sookhai said, when he thought about his children and grandchildren, "Me mind broke" ("Here" 1). This dramatic example of the conflicted moment of departure was not isolated. The newspapers of the period also stated that forty-three others changed their mind that day ( $15 \%$ of intended repatriates) ("But 44 " 1$)$. Why were individuals seized with dread at the moment of leaving? An answer may lie with Mishra, who points to ports as not merely sites of arrivals and departures, but echoes of an original journey that raises the spectre of becoming "individuals without an anchor" ("Bordering Naipaul" 224; Fanon qtd. in Hall 237).

According to the M.V. Resurgent's manifest, 258 adults and children eventually returned to India (Guyana Register). Most were older and had spent the greater part of their lives in Guiana raising their families (" 300 "). In some cases, up to three generations were returning, as many ex-indentured labourers were taking their "pickney" and "grand-pickney" (children and grandchildren) back (Ramcharan; "Repatriates Get Set"). However, for some passengers, "returning" to the Motherland was possible only as a visitor. As considerably less passengers registered than anticipated, space was opened to tourists (Ramcharan). Eight passengers paid full fare (i.e., were not repatriates), including the legislator who referred to the trip as a waste of funds and a young woman pursuing medicine at the University of Calcutta ("But 44" 1).

The M.V. Resurgent left Georgetown's wharf on September $4^{\text {th }}, 1955$, sailing south to the port of Recife, Brazil, then to Cape Town, South Africa, around its southern most tip (the Cape 
of Good Hope or Pagla Samundar), then onto Columbo, Ceylon finally arriving at its destination along the Hughli River, Calcutta on the $12^{\text {th }}$ of October, 1955 (Ramcharan). It traveled the same route and time of year as its predecessors (Laurence 363). Historians record the M.V. Resurgent as the only return vessel to have no deaths at sea (Nath 75); however, this was a fine distinction. According to Ramcharan, one woman was gravely ill on board the M.V. Resurgent and later died upon arrival in Calcutta; therefore, in the entire history of return journeys, mortality was a constant.

For young passengers on board the M.V. Resurgent who only knew India "from glowing pictures painted by their fathers and mothers and grandparents" ("But 44" 1), the familiar search for home and its continual deferral is foreshadowed. Front page headlines on the day of departure read: "Going home...to a home they never saw." A reporter quotes the intentions of a fourteen year old youth who, though yet to arrive in India, hoped to return to Guiana after ten years ("Indian Repatriates"). What emerges from this narrative is a clear sense that an arrival at "home" is elusive; what remains constant is the state of being in transit.

\section{Decolonisation: Guiana}

The significance of the last return journey is more than a temporal marker as indicated in epigraphs such as "last" or "end of a chapter." The M.V. Resurgent's significance lies in the opportunities it affords for theorising Indo-Caribbean diaspora, specifically in regard to decolonisation and the break with India (as the last official journey) (Mohabir and Simpson 492). As noted previously, both return passage and decolonisation raised the fundamental question: Where is home? hooks response to this question is: "At times home is nowhere" (148). All diasporas are haunted by a fear that home is illusory, i.e., that one can be forced out of home, similar to the Jewish experience (Mishra, "Impossible Mourning" 33). Seeking identification 
with a collectivity can be a strategy to minimise the fear of "unbelonging," especially among those who are marginalised. Although by 1955 Guiana had replaced India as the homeland in the imagination of most Indo-Guianese, especially since Guyana's own independence was in sight (Ramdin 202), the road to independence was not smooth. Independence struggles laid bare underlying racial tensions in Guianese society (Tinker, Banyan 62). Therefore, one understanding of the sentimental reasons for the last voyage is a retreat to the solace of "oneness." This leads to a second question: Who could be Indian? Contending constructs of "Indian-ness" arose in response.

The independence struggles in Guiana and India were linked by a shared desire for freedom. In the fight for Guiana's independence, a turning point was the infamous shootings at Enmore sugar estate. In 1948, police fired on a crowd of six hundred recently unionised plantation workers who were protesting labour conditions; five workers were killed, becoming the "Enmore Martyrs" (Rabe 27). This event affected the national psyche, but in particular the Indo-Guianese community, as sugar estate strikers were inevitably Indo-Guianese and the police force Afro-Guianese (Tinker, Banyan 57). Ramcharan noted the tragic events at Enmore were on the minds of returnees, but he did not consider it a primary push factor (Mohabir and Simpson 497). ${ }^{35}$ With tumultuous conditions in Guiana, it is possible returnees may have looked back for a sense of belonging, embedded in their enthusiasm for India's independence.

Following the Enmore shootings, resistance to colonial rule grew and within five years Britain granted British Guiana an "advanced" colonial constitution, allowing free elections for the first time in 1953 (Tinker, Banyan 67). Dr. Cheddi Jagan, leader of the People's Progressive Party (PPP) and on the verge of becoming the first "communist" leader in the West, won the overwhelming majority of votes (Naipaul, Writer 489 ). This represented a radical break not only 
in political philosophy as the PPP were socialist, but in leadership: Jagan was not white (Naipaul, The Middle Passage 139). He was the son of Indian indentured labourers and the first British Caribbean-born national leader. Unfortunately, this early victory for independence was taken away after only 133 days in office when the PPP government was dismissed, the constitution suspended, and British troops called in due to American and British trepidation about left-leaning governments in the post-World War II climate of Cold War (Tinker, Banyan 67). The victory of the PPP represented a rejection of the old order, e.g., plantocracy elites, British rule, and domination of Canadian missionaries; but once the PPP asserted power, they were ousted from office (Ramdin 199).

To seek international support against their undemocratic expulsion from office, Jagan and then Minister of Education, Forbes Burnham, flew to India in 1953. Their trip was welldocumented in the Indian newspapers, shedding light on the points of unity and disconnect between Guiana and India. In Delhi, arrival of the Guianese politicians was celebrated by the public (Tinker, Banyan 67); Jagan and Burnham were greeted with garlands, flags of Picasso's peace doves, and cries of "Jagan Zindabad" and "Burnham Zindabad" (Long live Jagan; Long live Burnham) from the crowds ("Arrival"). Jagan looked to India not for protection, but for solidarity: "We expect a great deal from India, as India is the champion of the coloniallydepressed people, and has recently come out of the shackles of imperialism" ("Problems"). In his address to India's House of Parliament, Burnham expressed similar hopes for self-determination: We have learnt a great deal from the struggles which you, the Indian people, have waged. ...We in British Guiana, Africans and Indians, celebrate the Indian Independence Day in British Guiana every year because to us it is a symbol; it is a beacon light; it is 
something that tells us that one day we, other colonial peoples, will be masters of our own country. One day we shall also be free. ("In Guiana") ${ }^{36}$

However, India declined to raise Guiana's situation at the United Nations and, suffice to say, Jagan and Burnham received little official support from India (Rabe 49). Tinker notes that while Nehru expressed sympathy for Guiana's plight publicly, he instructed the Indian Parliament that sympathy was not a sufficient reason for intervention (Banyan 68). Therefore, Mother India did not play the role of protector for its diasporic citizens nor did the sub-continent choose to use its political leverage to offer solidarity in a time of crisis. Guiana was left isolated with support neither from the East or the West. For many Indo-Guianese, the lack of Indian state concern regarding injustices in Guiana likely dislodged the centrality of India in the imagination of diasporans.

Tinker, one of the most comprehensive historians of the Indian diaspora, identifies the destabilisation of the PPP government as a precipitating factor behind the last repatriation (Banyan 68). However, Ramcharan's oral account refutes the authoritative version. Ramcharan notes that the majority of returnees were from the countryside (the ship's register indicates most lived on sugar estates, not urban areas), and he suggests that Indians residing in the estates were isolated from the political happenings of Georgetown. Seepersaud Naipaul (V.S. Naipaul's father) also wrote of differences between the unchanging "little Indias" of the rural villages in comparison to the "hotchpotch and polyglot [urban] towns," suggesting closer connections to India in the rural areas and less so in the creolised communities in town (99-100). Far from Georgetown, local issues directly affecting sugar estates were more likely to have been influential-at least for those whose return was a situational response to local uncertainties. 


\section{Decolonisation: India}

Hall notes that collective identity was an important organising tool to mobilise anticolonial resistance (234); both Gandhi and Nehru appealed to diasporic Indians to support independence. In 1937 Nehru said: "Our countrymen abroad must realise that the key to their problems lies in India. They rise or they fall with the rise and fall of India...Surely, the only way is to put an end to our subjection, to gain independence and the power to protect our people wherever they might be..." (qtd. in Tinker, New System 378). Nehru linked the nationalist cause unequivocally with its diaspora through a conception of collective Indian identity. Around the same time (1938) in Guiana a member of the BGEIA wrote, "I am loathe to think that we [IndoGuianese] can work out our own destiny, unaided by the Motherland" (P. Ruhomon 107). By this point the BGEIA was arguing against physical repatriation, but they did not foresee a future separate from India. This complex relationship between centre and diaspora was one of simultaneous reinforcement and (later) displacement of collective identity (Mishra, "Diasporic Imaginary" 431).

The centre (originary home) was soon redefined by its own historical trauma-the dismemberment of India. Partition resulted in the largest migration in history, with an estimated twelve million people moving across the newly created borders of India and Pakistan; ensuing sectarian violence between communities (e.g. Hindus, Muslims, and Sikhs) left up to two million people dead (Butalia 3). As India struggled with who would define the ideal community of the new nation-state, neither Gandhi nor Nehru considered the place of Indians overseas (Ray 283). Moreover, diasporic Indians were no longer Indians as Nehru reminded Parliament: "This House gets mixed up. It wants to treat them as Indians and with the same breath it wants complete franchise for them in countries where they are living. Of course, the two things do not go 
together" (qtd. in Juneja 135). Hence, the project of the Indian nation-state called on diaspora to legitimate its struggle, but had no explicit need for diaspora after liberation. State-defined Indianness was now contained within its territorial borders. Despite the inspiration offered by Indian liberation, not only to Indo-Caribbeans but more broadly all colonised peoples, India chose to protect its infancy as a nation-state and not challenge the Empire's use of force in Guiana. The relationship of India as the "natural" locus of support for its diaspora had altered.

In spite of the return movement afoot in the Caribbean, Nehru appealed to IndoCaribbeans to build their future in the countries where they had settled (Selvon, "Three" 16$)$. The Indian government wrote to Guiana formally requesting that the colony discourage repatriation, and sent materials to disseminate the message. Ramcharan personally translated a notice into Hindi to inform the public of Nehru's appeal. However, Indo-Guianese desiring return persisted in their efforts, refusing to believe that the Mother country would discourage them: "Guiana government nah want. They tryin' fool us" they said (Mohabir and Simpson 498). In 1954, a list of all those registered to return was shared with the Indian Commissioner and he wrote to each intending repatriate urging them, based on economic conditions in post-partition India, to reconsider, but the Guianese psyche accustomed to years of paternal dissuasion "paid no heed" to the suggested difficulties (Guyana "Letter"). Returnees were determined to cross the Kala Pani and negotiate their own relationship to the centre-on their terms.

Consider the following paragraph in The Jumbie Bird which expresses the changing realationship between India and the Caribbean:

...[H]e could hear the [Indian] Commissioner's voice of the evening before saying that he was not sent to Trinidad to revive old quarrels, that the past was dead and over, that India was no longer at odds with the British and that India wished that they would settle 
here and try to make this place their home. And when the meaning of his words struck Kale Khan, he felt a great physical jolt that sent him spinning, plunging into nowhere. He felt a horrifying loneliness seize him...there was no home, no land peopled by men among whom he could walk and feel that it was his world, his home, a world that did not leave him alien and stranger in the streets...(199-200).

This paragraph depicts the lack of surety of one's place in the world and the emotional rift of separation at the dissolution of colonial relationships. As well, it marks a policy shift from the nineteenth-century colonial Indian government's adamant protection of the right to return. During the period of Indentureship, India was a colony of Britain and return rights functioned to facilitate a steady supply of subservient labour to British-owned sugar estates. The role of the colonial emigration office within the Indian government then was not simply to protect Indians overseas, but also to fulfill the labour demands of plantation economies. However, a decolonised India no longer had direct ties to Caribbean planter interests, nor a corresponding economic need to maintain the right of return.

It is not inconceivable that the first country to achieve independence from British rule preferred to disconnect itself from the history of Indentureship. As Gilroy notes, it is easier to turn away once symbolic and political liberation is achieved, if not material and economic liberation (71). The place, or lack thereof, of ex-indentured Indians in a free India was determined by the protocols of nation-states, not diasporic ties. Then again, the consequences of Empire had turned the majority of ex-indentured Indians and their descendants into settlers in the Caribbean. They became "a people, while still recognizably Indian, no longer belonged to India," and a people who, shaped by their new environment "no longer remained a faithful echo of the old" (Juneja 132). Thus Kale Khan's rejection by Mother India could be interpreted as either a 
betrayal of the homeland, or otherwise as his refusal to see "what we have become" since the ruptures of history.

Drawing upon a range of resources in this chapter, the last return is situated in relation to tensions arising at the time of decolonisation. Emotional reasons for the 1955 repatriation possibly included dreams of dying in the homeland, desire to restore family ties, nationalist pride, resistance to colonialism, or imagined community/territorial belonging. Logical explanations for repatriation included economic conditions, cultural marginalisation, or political instability in the colony. Foremost, however, Ramcharan proposes that India's Independence was the impetus for the last repatriation. Delving into the politics of emergent nations suggests that diasporic identities were shifting away from territorial homeland to memories of experiences, mediated by historical circumstances (e.g. liberation of home(s) or political necessities). 


\section{CHAPTER 3: GOING HOME...TO A HOME THEY NEVER SAW.}

"[T] he very meaning of 'home' changes with experience of decolonization. At times home is nowhere. At times, one knows only extreme estrangement and alienation. Then home is no longer one place. It is locations" (hooks 148).

This section explores both the anecdotal experiences and theoretical implications of $\underline{\mathrm{M}} \mathrm{V}$.

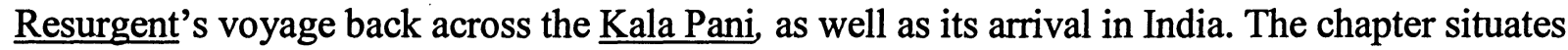
the narrative of the last return within a specific historical setting and set of relationships, and as part of a long line of return journeys. In addition, the meaning of the last official journey is examined, alongside the accompanying challenges of resettlement.

Looking back on the 42-day voyage, Ramcharan vividly remembered the emotional distress of passengers. Passengers required "comfort" and "consoling" as Ramcharan sensed a perceptible anxiety onboard. The seas were rough around the Pagla Samundar, making the ship "tremble like a calabash," and possibly prompting passengers, as it did Ramcharan, to think of those earlier journeys on less robust ships (Mohabir and Simpson 495). The potential for death was present on all ships; there was not a single one that sailed without death or disease (Mishra, "Bordering Naipaul" 198). In fact, Mishra states there are no journeys but the first; it overshadows all those that follow ("Bordering Naipaul" 224). In other words, indentured labourers would often recall the initial passage as the most traumatic moment of their lives, and it was during times of passage that thoughts turned homeward (Mishra, "Bordering Naipaul" 198). 
To ease the apparent distress over the decision to return home, Ramcharan organised a social gathering, and in his speech to the repatriates, he urged them to "adjust to .... a new country" (noticeably he did not term India as the originary homeland):

I told them: "Do your best to adjust and re-settle. Keep an open mind. Do not worry about Guiana, try to adapt." Such words emboldened my talk. When you go to a new country, you find yourself in new situations, and it is in your interest to move on. As I spoke, they were crying. [Long pause as Ramcharan looked back.] I felt emotional too. They all held me tightly and made me cry, and with one voice, they said thank you. That was really an experience of Jahaji (Mohabir and Simpson 502).

In the quote above, Ramcharan invoked Jahaji to describe the bonds that developed on the M.V. Resurgent. As noted in chapter one, $\underline{\mathrm{Jahaji}}$ was created out of common experiences in ships, and was also a means to resist colonial tactics of cultural devaluation and divide and rule. On this journey with Indo-Caribbeans in a position of colonial authority, the use of Jahaii legitimates the shared experience of voyage. It is also reminiscent of a link between earlier voyages that necessitated identity shifts and the transformative experience that awaited the last repatriates.

Ramcharan's wife, at home in Guiana, listened daily to All India Radio for news of the ship's arrival. When the ship reached India on October 12, 1955, she heard Nehru's reaction: Thetar log agaye ("The stubborn people have come") (Mohabir and Simpson 502). The first chapter implies that a diaspora requires a homeland from which it is dispersed to construct its identity; therefore, diaspora has a relationship to a nation-state or territory, even though the concept of diaspora transcends borders. Although the state cannot impose an individual or even communal identity, the rejection of the state was a signal that a homogenous Indian identity was 
no longer tenable. Nehru's active discouragement of the last return marked the official split between India and the Indo-Caribbean diaspora (Simpson).

Upon arrival, the Resurgent followed the routine set out for return journeys, i.e., Ramcharan cabled news of the ship's arrival to the Protector of Emigrants whose role was to carry out an inspection of passengers, ship and supplies, and attend to any medical emergencies. Remitted savings were then distributed, and train tickets purchased to "home" villages (Mohabir and Simpson 503-504).

Ramcharan shared an interesting story of one man's, a fakir (beggar), return. The Protector of Emigrants laughed when he saw the fakir, and greeted him warmly. This individual traveled back and forth between Guiana and India to earn his living as a street beggar, therefore subverting the system of Indentureship (Ramcharan). He also had the highest remittance of any returnee (Guyana Register). As Ramcharan recalled, the Protector of Emigrants, though concerned about repatriates, was not worried about the fakir. The Protector recognised that out of everyone on board, he was the only person familiar with the "real" India (Mohabir and Simpson $501)$.

For others returning after a long absence or for the first time, the actual conditions in India were disorienting, if not disturbing. Partition had resulted in the upheaval not only of families, but entire villages (Butalia 3), making it difficult to go "home." Earlier returnees had also had trouble reaching their villages. Many ended up in a "makeshift settlement" along the Hughli River (Mohabir and Simpson 503). It was here that Ramcharan found an old school friend, Chanchal, who had returned previously. However, Chanchal was not the same man Ramcharan knew in Guiana. Mirroring literary references to madness as a result of displacement (e.g., Brand's In Another Place, Not Here), Chanchal apparently had a nervous breakdown and 
was living under indigent circumstances. Ramcharan became worried about the future awaiting repatriates. One large family had returned with a number of young children; Ramcharan gave them some food from the ship's stores. He did not know what else to do, and later worried if they ever "made good." Little is known about the experiences, memories or traumas of those who eventually re-settled in India following the M.V. Resurgent's voyage.

Narratives of return that tell similar tales of dislocation and disillusionment were well known by this time. Chanchal had returned to India with his mother, leaving siblings behind in Guiana. Upon hearing of the difficulties they encountered adjusting to India, his siblings pooled their money to pay for the mother's passage back to Guiana, unfortunately leaving Chanchal behind in Bhaboo Ghat, the slum beside the Hughli river (Mohabir and Simpson 503). Ramcharan himself heard directly from Chanchal's mother about the "appalling poverty" of India; she strongly advised others against returning. In the long history of return, many repatriates never moved beyond Calcutta (Laurence 370). As Ramcharan points out, they would have had difficulty adapting to the city, as everyday life was conducted in Bengali and most returnees spoke Bhojpuri (a north Indian dialect) (Ramcharan). Those in positions of power were also concerned about the "wisdom" of return. Reverend C.F. Andrews (a friend and supporter of Gandhi) noted ex-indentured labourers returned to find not their home villages, but the slums of India (Jacob 47). Sugrim Singh also expressed his disapproval of the last repatriation, citing similar stories of alienation. He noted that "these people"37 who returned to their villages were unable to find anyone they knew or who knew them, and became wanderers across the Indian countryside ("Back to India Waste" 4). Others faced challenges re-integrating into the village structure. Early repatriates recount similar stories of returning to villages where they were no longer recognised. They would be admitted to the village until their savings were spent, at which 
point they were driven out as pariahs (Hill 51; Ramesar 191; Ray 271). Although these difficulties were familiar by 1955 , ancestral connections (however fragile) still lingered, and spoke to the hearts, not necessarily the minds, of those determined to return.

Crossing the Kala Pani was the most common reason for losing one's place in the Indian village. An ocean crossing often signaled defiance of village elders who opposed emigration (Ramesar 193). The Kala Pani also had a negative association with voyages to the island of Andaman, a convict settlement (Mangru El Dorado 14). Most importantly, however, Kala Pani crossings were a transgression of Hindu beliefs which viewed ocean voyages as a defilement of caste, family and village (Mehta 5; Ramcharan). "Real" Indian life was structured along lines of kin, village, language, region and so forth, but in the West Indies these distinctions lost meaning as Jahaji bonds solidified. Once in India, however, fault lines re-surfaced. Many spouses were left behind in Calcutta (or Guiana) as they were now the wrong caste or creed and would hinder re-integration (Mishra, "Bordering Naipaul" 201-202). Indian identity was narrowly defined, and it was difficult to escape the consequences of crossing the Kala Pani. Moreover, whether one lived in Guiana or India, a voyage across the Kala Pani was a signal of outsider status.

Likewise, the original crossing of the Kala Pani transformed identities and attitudes that were not easily transplanted back to India (Simpson "Responding"). As explained to the Sanderson committee (a 1910 enquiry into the system of Indentureship), "When a coolie is leaving India...you see him coming and touching my feet. When the coolie returns, he puts his hand out and says, 'How do you do'...There is a difference between a coolie leaving India and a coolie returning" (Warner qtd. in Ramesar 193). After living abroad, Indo-Caribbeans no longer possessed the customs or behaviour characteristic of "Indians." Later, in a 1938 debate in the Indian legislature, a representative also commented on differences: "Most of the Guiana Indians 
have adopted ... a hybrid, a half-baked Afro-American culture. They are neither Indians nor are they Americans" (qtd. in Juneja 136). The representative's choice of words suggests IndoCaribbeans were compromised Indians; their identities had shifted to the point that differences, not sameness, was more salient. In Jagan's assessment: "Indians of the diaspora were not exactly the same as the roots from which they sprang" (Jagan qtd. in Mishra, "Bordering Naipaul" 227).

Perhaps with dashed hopes, returnees realised they had changed, and India too had changed. Bewilderment with the new India, one substantially different from the "frozen in time" village of the imagination, and lacking a place within the nation-state, led a number of repatriates to seek out Ramcharan. To his surprise, a group of about forty people gathered in his hotel lobby a few days after landing (Ramcharan qtd. in Birbalsingh, Pillar 69). As he recalls, repatriates were emotionally distraught, crying, "We don't know where to go. We ain't got nobody" (Mohabir and Simpson 504). In hindsight, the cumulative signs of trauma were evident upon departure, onboard the ship, and on arrival. Their experiences were reminiscent of the first outward journeys where loss of connections and an unmoored identity was transformed into a reconstituted identity relative to others and to the new environment, beginning in the space of ships. As a moving vessel across the Atlantic, the M.V. Resurgent highlights the re-siting and reconstituting of identity that occurred in the in-between spaces. Unable to find their personal place of belonging (e.g., family or village), and lacking a communal affiliation with postcolonial India, returnees desired the only space that offered the comfort of home-Guiana. India was no longer the "we" in "we country"; they had undergone a permanent shift in their collective belonging. The desire to return to Guiana upon witnessing the real setting of India was not unique to the 1955 journey. Often returnees, having reached no farther than Calcutta's port, would go to such lengths as re-indenturing themselves to return to Guiana (Ramdin 154). Indian- 
ness as a communal identity was therefore challenged, not only by the fractures of India's independence, but by something more deeply abiding - "the memory of home" (Joseph 57).

In his capacity as Repatriation Officer, Ramcharan's role was to protect the welfare of repatriates and assist with their re-settlement. Even though he chided returnees on the consequences of their choice ("Friend, what to do? You opt for this."), he agreed to speak to the Protector of Emigrants in Calcutta to determine possible arrangements (Mohabir and Simpson 504). Archival documents note considerable correspondence occurred between New Delhi and Georgetown regarding repatriates who wished to return to Guiana (Guyana Savingram). As Ramcharan recalls, those who were fortunate to borrow money from relatives purchased a ticket on a Nourse line cargo ship to Trinidad, then took a schooner across to Guiana. About twentyfive people were able to return to Guiana in this way (Mohabir and Simpson 504). For those without options, Ramcharan made arrangements in Calcutta for temporary shelter in a home for internally displaced refugees. In the end, repatriates took a long and difficult route to come full circle to an understanding of who they were and where was home, but throughout they had asserted their right to insist on belonging to a place determined by them, not inflicted by geopolitical realities.

\section{Re-thinking Home}

"[T]he very meaning of "home" changes with experience of decolonization," hooks wrote. Under the particular optimism of decolonisation, the Indo-Caribbean diaspora attempted one last grasp at India as a homeland, spurred on by sentimental, even patriotic feelings and political actions in the Caribbean. However, upon their actual return to India, they discovered India was not quite home. As hooks suggests, "At times home is nowhere" (148). India was coping with the aftermath of imposed and fragile borders. Returning diasporic citizens were a 
thorn in the side of the new nation-state, a distraction from the process of nation-building. Moreover, they no longer fit into a narrative of "Indian-ness" as defined by political leaders. There was simply no place for repatriates in the new India. hooks goes on to suggest, "At times one knows only extreme estrangement and alienation" (148). Repatriates did not feel comfortably at home in the Caribbean, and left to return to the place where they presumably belonged, only to find that their history had unraveled from the centre. Their memories of home were disrupted by the effects of Partition, but more so, India had become a strange place, and they were strangers in it. As hooks concludes, "Then home is no longer one place. It is locations" (148). Even with strong determination, India could no longer be imagined as home. In India, it was not possible to be both one and something other (Indian and Caribbean). Although India remained the heritage of repatriates, it was the Caribbean to which they returned. Home was transformed into a memory transported with each journey, and carried over to many places.

Thus, the last return is not a quirky story about people who did not know their place; it is an important narrative about the confrontation of imperial and state practices; it is an illustration of the lasting impact of Jahaji and creolisation; and lastly, it is an illustration of the process through individuals and communities come to know home. It is a history that demands to be told. 


\section{CONCLUSION}

"You cannot be entirely Oriental, nor entirely Occidental; you can be no more entirely Western than you can be entirely Eastern...you will be distinctly West Indian." (S. Naipual qtd. in Juneja 144)

After the M.V. Resurgent, no more return indenture/ships sailed to India. Although the colony still honoured the right of return, only one formerly indentured labourer and his wife claimed return passage after the last ship (Nath 160). While Indo-Caribbean people had ancestral links to India, the core of their communal and self-identity had altered; they had become rooted in the Caribbean. A homeland held dear and idolised for a long time was fractured and obscured beyond recognition, to the extent that it only existed in memory (Ramdin 203). Although they had attempted to return from exilic conditions, with time and distance from India, they were reconstituted as strangers when they returned, out of place in the land of their birth. Their romantic or nostalgic memories of Indian were buried in the past. Similarly, when asked why many repatriates were unable to find a place of belonging in India, Ramcharan established a spatial and temporal link between outward journeys from the Caribbean, and paralleled their experiences to his own later outward journey from the Caribbean to Canada. He said after thirty years in Canada, "If I go to Albion [Guyana] now, I'd be a stranger; that is what happened to the people who lived so long in Guiana and went back to India. They went to their place [of origin], but there were too many changes. They no longer fit in" (Mohabir and Simpson 504).

Thinking of "home" and "away from home" as separate concepts or even oppositessuggests "away from home" is synonymous with residing in a strange land (Chambers qtd. in Ahmed 88). However, for an Indo-Caribbean diasporic consciousness, home is both 
familiar yet strange, resulting in a constant sense of not quite belonging and yet no going back, which is common to many marginalised communities. Birbalsingh argues that Indo-Caribbeans posses an exilic quality, becoming in effect "unanchored and homeless souls" (qtd. in Simpson "Testing"). Having one's destination defined as home yet never arriving at it has become a significant feature of the Indo-Caribbean consciousness (Mishra, "Bordering Naipaul" 223). One might then consider Indo-Caribbeans as wanderers. Since the Whitby, they have been on the move, not belonging to India, or fully to the Caribbean, or even to new diasporic places such as Canada (Mohabir and Simpson 492). Mishra interprets the "familiar temporariness" of their homes as a "virtue of necessity," perhaps emerging from postcolonial ethnic tensions that impacted almost all old Indian diaspora communities ("Bordering Naipaul" 227; Tinker, Banyan 20). Indo-Caribbeans, then, have adjusted to multiple migrations - not out of choice, but out of necessity.

The voyage of the M.V. Resurgent, while a stark reminder of the transience of home, does not necessarily belie a rooted existence. The last return reveals that the "we" in Hall's "who we are" was, for re-repatriates, the Caribbean; the break was with India. Indo-Caribbeans, in a process akin to walking on water while keeping the self afloat (not adrift), built new home places as they crossed oceans (K. Brathwaite). Brathwaite indicates that continuing connections remain between multiple points, even if only visible in ancestral or cultural residues (K. Brathwaite). Thus memories of home and "long ago" are carried, in some way, through the historical migrations outward. Brathwaite's assertion is a form of "imaginative coherence to the experience of dispersal," an example of identity tied to a cultural reference point (e.g. ancestral home) that Hall characterises as one vector of (Caribbean) diasporic identity (235). The reaction to a free India, as seen in expressions of solidarity within the Caribbean and in the desire for unity, was an 
ancestral thread that pulled Indo-Caribbeans back to India. Indo-Caribbean is an identity that emanates from such historical specificities; and as Juneja notes, links between self-conception and historical consciousness run deep in the Caribbean (144).

This raises an earlier concern. If historical dynamics are at the core of Caribbean identity, why has the selected "facts" of Indo-Caribbean history omitted the story of the M.V. Resurgent? Despite the prominence of Indo-Caribbeans in Caribbean nationalist struggles, the small number of returnees and the range of responses to Caribbean identity that existed as a result of creolisation, expelling the parts of history that countered claims of (a singular) belonging to the Caribbean was perhaps necessary to navigate postcolonial tensions. The ocean as a metaphor supports this understanding of home as tenuous as the voyage around the Pagla Samundar. Consequently Indo-Caribbean history focused on arrival and settlement in the Caribbean, and the last repatriation was conceivably an anachronism.

The second vector of which Hall spoke, "where we are going" since the interventions of history, is expressly evident in the hitherto missing narrative of the last return. Indenture/ships connected India to the Caribbean, and it was in the process of transit across oceans that IndoCaribbeans came to understand themselves. Specifically, a dialogue of return (a political and personal process, as well as a metaphorical and physical negotiation) revealed the tenuousness of home, either "here" or "there." In re-crossing the Kala Pani, repatriates did not find the comfort of a permanent home; instead, they experienced an unstable relationship between centre and diaspora. Old affiliations such as language, religion, or ethnicity were not sufficient for collective identity. The "Indo" in Indo-Caribbean identity had become cut loose, de-territorialised from India. Yet identity was not simply re-territorialised onto the Caribbean (trading in one for other). Tropes of departure and return, and ships and crossings offer a concept of belonging that 
transcends homeland narratives, thereby shifting the centre of diaspora from a territory to lived experiences and memories of the past.

Re-repatriates excised feelings of ambivalence through journeys of return and re-return. Although the last repatriation was a conscious physical effort to return from exile, it was the last. Indo-Caribbeans are in exile from Mother India no more. Never again would an attempt at rooted return to the homeland (i.e. India) be imagined as collectively possible, or even desired. Due to an irrevocable process of diasporisation, the only option for Indo-Caribbeans (the descendants of indentured labourers) to "return" to India today is as a tourist or a visitor. Yet, even a transient return still evokes a suppressed anxiety reminiscent of the last return:

India is for me a difficult country. It isn't my home and cannot be my home; and yet I cannot reject it or be indifferent to it ... I am at once too close and too far. ... It has taken me much time to come to terms with the strangeness of India, to define what separates me from the country and to understand how far the Indian community in the New World diverged from the attitudes of people to whom India is still whole... In India I know I am a stranger; but increasingly I understand that my Indian memories, the memories of that India which lived on into my childhood in Trinidad are like trapdoors into a bottomless past (Naipaul "India" 8).

Naipaul's quote hints at the submerged connections that still remain between India and the Caribbean. The next leg of this research (and journey) is to uncover the stories on the other side of the Kala Pani-the oral histories of those who permanently re-settled in India, after time in the Caribbean. 


\section{Works Cited}

"250 Repatriates Leaving in Emigrant Ship 'Resurgent' " The Daily Argosy 4 Sept 1955: Front Page.

“250 Trinidadians to Leave for Liberia by Year End" The Daily Chronicle 19 August, 1955. N. Pag.

"300 Register for Repatriation to India" The Daily Chronicle 28 July 1955. N. pag.

Ahmed, Sara. Stranger Encounters: Embodied Others in Post-Coloniality. London: Routledge, 2000.

Anderson, Benedict. Imagined Communities: Reflections on the Origin and Spread of Nationalism. New York: Verso, 1991.

“Arrival in Delhi." The Hindu 21 November 1953. N.pag.

"Back-to-India Project A Waste of Money, Says Sugrim Singh " The Daily Argosy 19 August 1955: 4.

"Back to India Ship Arrives, Leaving on Sunday" The Daily Chronicle 1 September 1955: Front Page.

Birbalsingh, Frank. "Chhablall Ramcharan." From Pillar to Post: The Indo-Caribbean Diaspora Toronto: TSAR, 1997. 65-74.

Brah, Avtar. Cartographies of Diaspora. London: Routledge, 1996.

Brand, Dionne. In Another Place, Not Here. Toronto: Vintage Canada, 1997.

Brathwaite, Edward. Contradictory Omens: Cultural Diversity and Integration in the Caribbean. Mona, Jamaica: Savacou Publications, 1974.

Brathwaite Kamau. MiddlePassages: A Lecture. With An Introduction by Elaine Savory. Prod.

H. Simpson. CD. Toronto: Sandbury Press, 2006.

Braziel, J.E., and A. Mannur. 'Nation, Migration, Globalization: Points of Contention in 
Diaspora Studies." Theorizing Diaspora. Ed. J.E. Braziel and A. Mannur. Oxford, UK: Blackwell, 2003.1-22.

Brodber, Erna. "Oral Sources and the Creation of a Social History of the Caribbean." Jamaica Journal 16.4 (1983): 2-11.

"But 44 Change Their Minds" Daily Chronicle 5 September 1955: Front Page.

Butalia, Urvashi. The Other Side of Silence: Voices from the Partition of India. Durham, North Carolina: Duke University Press, 2000.

Butler, Kim. “Defining Diaspora, Refining Discourse.” Diaspora: Journal of Transnational Studies 10.2 (2001): 189-219.

Carter, Marina, and Khal Torabully. Coolitude: An Anthology of the Indian Labour Diaspora. London: Anthem Press, 2002.

Clarke, Austin. Growing up Stupid under the Union Jack : A Memoir. Toronto: McClelland and Stewart,1980.

Cohen, Robin. Global Diasporas: An Introduction. Seattle: University of Washington Press, 1997.

Comins, D. Note on the Abolition of Return Passages to East Indian Immigrants for the Colonies of Trinidad and British Guiana. Georgetown, Guyana, 1894.

Dabydeen, David. “Indo-Guyanese Resistance.” Indo Caribbean Resistance. Ed. Frank Birbalsingh. Toronto: TSAR, 1993. 27-32.

Dei, George J. Sefa, and Alireza Asgharzadeh. "The Power of Social Theory: The Anti-Colonial Discursive Framework." Journal of Educational Thought. 35.3 (2001): 297-323.

Dev, Ravi. Foreword. Centenary Celebration of the Arrival of Indians to British Guiana (18381938). By British Guiana East Indian Association. Ed. Baytoram Ramharack. 1938. San 
Juan, Trinidad: Chakra Publishing House, 2001. vii-xi.

Dossa, Parin. Politics and Poetics of Migration: Narratives of Iranian Women from the Diaspora. Toronto: Canadian Scholars' Press, 2004.

Dwarka, G.R. "Good-bye.” An Introduction to the Poetry of the East Indian Diaspora. Ed. Kampta Karran. Georgetown, Guyana: Offerings. 1991. 43-44.

Espinet, Ramabai and Elaine Savory. "A Sense of Constant Dialogue-Writing, Woman and Indo-Caribbean Culture." The Other Woman: Women of Colour in Contemporary Canadian Literature. Ed. Makeda Silvera. Toronto: Sister Vision Press, 1995. 81-93.

Ganz; Marshall. "The Power of Storytelling in Social Movements." John F. Kennedy School of Government. Harvard University. 12 July 2005 $<$ http://ksghome.harvard.edu/ mganz/publications.htm>.

Gilroy, Paul. "The Black Atlantic as a Counterculture of Modernity." Theorizing Diaspora. Ed. J.E. Braziel and A. Mannur. Oxford, UK: Blackwell, 2003. 49-80.

"Going Home... to a Home They Never Saw." The Daily Chronicle 5 September 1955: Front Page.

Gopie, Kamala-Jean. "The Next Indo-Caribbean Generation in Canada" Indo Caribbean Resistance Ed. Frank Birbalsingh. Toronto: TSAR, 1993. 62-66.

Guyana. National Archives of Guyana. Register of Return Immigrants who Embarked at the Port of Georgetown, British Guiana for Calcutta in the ship M.V. Resurgent which sailed $4^{\text {th }}$ of September 1955. 4 September, 1955.

---. --.. "East Indian Immigrants - Repatriation" Executive Council Minutes, April 1954.

---. ---. "East Indian Immigrants - Repatriation" Executive Council Minutes, 9 February 
1955.

---. ---. "From Secretary State of the Colonies to Officer Administering the Government British Guiana" Savingram 652. 21 August 1956.

---. ---. "Letter to Ministry of External Affairs from the Office of the High Commissioner for the United Kingdom in India." 9 November 1956.

Hall, Stuart. "Cultural Identity and Diaspora." Theorizing Diaspora, Ed. J.E. Braziel and A. Mannur. Oxford, UK: Blackwell, 2003. 234-246.

Harney, Stefano. Nationalism and Identity: Culture and the Imagination in a Caribbean Diaspora. Kingston, Jamaica: University of the West Indies Press,1996.

"Here I'll Stay." The Daily Chronicle 5 September 1955: Front Page. Hill, Arthur. "Emigration from India." Timehri. VII (September 1919): 50-52.

hooks, bell. Yearning: race, gender, and cultural politics. Toronto: between the lines, 1990 . Hua, Anh. "Diaspora and Cultural Memory." Diaspora, Memory and Identity: A search for Home. Ed. Vijay Agnew. Toronto: University of Toronto Press, 2005. 191-208.

Hubel, Teresa. Whose India? The Independence Struggle in British and Indian Fiction and History. Durham, North Carolina: Duke University Press, 1996.

"In Guiana - India's support urged Dr. Jagan's Appeal” The Hindu 25 November 1953. N. pag. "Indian Repatriates' Departure In Pictures" The Daily Chronicle, 5 September 1955. N. pag. Jacob, C.R. Centenary Celebration of the Arrival of Indians to British Guiana (18381938) By British Guiana East Indian Association. Ed. Baytoram Ramharack. 1938. San Juan, Trinidad: Chakra Publishing House, 2001. 39-48.

Jayaram, N. "Introduction: The Study of Indian Diaspora." The Indian Diaspora: Dynamics of Migration. Ed. N. Jayaram. New Delhi: Sage Publications, 2004. 15-43. 
Jospeh, Clara. "Nation Because of Differences." Research in African Literatures. 32.3 (2001): $57-70$.

Juneja, Renu. Caribbean Transactions: West Indian Culture in Literature. London: MacMillan Caribbean, 1996.

Kale, Madhavi. Fragments of Empire: Capital, Slavery, and Indian Indentured Labour Migration in the British Caribbean. Philadelphia: University of Pennsylvania Press, 1988.

Kelly, Ninette, and Michael Trebilcock. The Making of a Mosaic: A History of Canadian Immigration Policy. Toronto: University of Toronto Press, 1998.

Khan, Aisha. Callalloo Nation: Metaphors of Race and Religious Identity among South Asians in Trinidad. Durham, North Carolina: Duke University Press, 2004.

Khan, Ismith. The Jumbie Bird London: MacGibbon \& Kee, 1961.

Lamming, George. Foreword. A History of the Guyanese Working People, 1881-1905. By Walter Rodney. Baltimore, Maryland: John Hopkins University Press, 1981. xvii-xxv. Laurence, K.O. A Question of Labour:Indentured immigration into Trinidad and British Guiana 1875-1917. Kingston, Jamaica: Ian Randle Publishers, 1994.

Lokaisingh-Meighoo, Sean. "The Diasporic Mo(ve)ment: Indentureship and Indo-Caribbean Identity." CERLAC Working Paper Series. Toronto: Centre for Research on Latin America and the Caribbean, York University, 1998.

Mahabir, Noor Kumar. The Still Cry: Personal Accounts of East Indians in Trinidad and Tobago during Indentureship, 1845-1917. Ithaca, NewYork: Calaloux Publications, 1985.

Mangru, Basdeo. Benevolent Neutrality: Indian Government Policy and Labour Migration to British Guiana 1854-1884. London: Hansib, 1987.

---. The Elusive El Dorado: Essays on the Indian Experience in Guyana. Lanham, 
Maryland: University Press of America, 2005.

---. Indians in Guyana: A Concise History from Their Arrival to the Present. Chicago:

Adams Press, 1999.

Mehta, Brinda. Diasporic (Dis)locations: Indo-Caribbean Women Writers Negotiate the Kala

Pani. Kingston, Jamaica: University of the West Indies Press, 2004.

Mishra, Vijay. “(B)ordering Naipaul: Indenture History and Diasporic Poetics” Diaspora: Journal of Transnational Studies. 5.2 (1996): 189-237.

---. “Diasporas and The Art of Impossible Mourning." In Diaspora: Theories, Histories,

Texts. Ed. Makarand Paranjape. Delhi: Indialog Publications, 2001. 24-51.

---. "The Diasporic Imaginary: Theorizing the Indian Diapsora." Textual Practice 10.3 (1996): 421-447.

Mohabir, Nalini and Hyacinth Simpson. "Resurgent (Rise Again): The Last Repatriation of IndoCaribbean Indentured Labourers.” Interventions: International Journal of Postcolonial Studies. 8.3, 2006. 487-505.

Naipaul, Seepersaud. The Adventures of Gurudeva. 1976. London: Heinemann,1995.

Naipaul, V.S. The Writer and the World: Essays. Toronto: Vintage Canada, 2003.

---. Finding the Centre: Two Narratives. London: Deutsch, 1984.

---. The Middle Passage: The Caribbean Revisited, London: Andre Deutsch, 1962.

---. India: A Wounded Civilization London: Penguin Books, 1977.

Natarajan, Nalini. "Reading Diaspora." Introduction. Writers of the Indian Diaspora. Ed.

Emmanuel Nelson. Westport, Conneticut: Greenwood Press, 1993. xiii-xix.

Nath, Dwarka. A History of Indians in Guyana. 1950. London: Self-published, 1970.

Parekh,.Bhikhu. "The Indian Diaspora." Global Indian Diaspora: Yesterday, Today and 
Tomorrow.Ed. Jagat K. Motwani, Mahin Gosine, and Jyoti Barot-Motwani. New Delhi:

Global Convention of People of Indian Origin, 1993. 8-10.

Persaud, Yesu. "Indians in Guyana." Global Indian Diaspora: Yesterday, Today and

Tomorrow. Ed. Jagat K. Motwani, Mahin Gosine, and Jyoti Barot-Motwani.

New Delhi: Global Convention of People of Indian Origin, 1993. 175-185.

“Problems of British Guiana, Dr. Jagan Seeks India's Support." The Hindu 21 November 1953.

N. pag.

Puri, Shalini. The Caribbean Postcolonial: Social Equality, Post-nationalism, and Cultural

Hybridity. New York: Palgrave MacMillan, 2004.

Rabe, Stephen. US Intervention in British Guiana: A Cold War Story. Chapel Hill, North

Carolina: University of North Carolina Press, 2005.

Radhakrishnan, R. "Ethnicity in an Age of Diaspora." Theorizing Diaspora. Ed. J.E. Braziel and

A. Mannur. Oxford, UK: Blackwell, 2003. 119-131.

Ramchand, Kenneth. Introduction. An Island is Small World. 1955. Toronto: TSAR, 1993. $\mathrm{v}-\mathrm{xxv}$.

Ramcharan, Chhabllal. Personal Interview. 4 June 2005.

Ramdin, Ron. Arising from Bondage: A history of the Indo-Caribbean People. London:

I.B.Tauris, 2000.

Ramesar, Marianne Soares. "The Repatriates." Across the Dark Waters: Ethnicity and Indian Identity in the Caribbean. Ed. David Dabydeen and Brinsley Samaroo. London: Macmillan Caribbean, 1996.175-200.

Ramharack, Baytoram. Introduction. Centenary Celebration of the Arrival of Indians to British 
Guiana (1838-1938). By British Guiana East Indian Association. Ed. Baytoram

Ramharack. 1938. San Juan Trinidad: Chakra Publishing House, 2001.1-23.

Ramlogan, J. Editorial. Centenary Celebration of the Arrival of Indians to British Guiana

(1838-1938). By British Guiana East Indian Association. Ed.Baytoram Ramharack.1938.

San Juan Trinidad: Chakra Publishing House, 2001. 30-34.

Ramraj, Victor. "Still Arriving: The Assimilationist Indo-Caribbean Experience of Marginality."

Reworlding: The Literature of the Indian Diaspora. Ed. Emmanuel Nelson. Westport, Connecticut: Greenwood Press, 1992. 77-85.

Ray, Karen. "Indenture Identity and Indian Freedom Struggle." Ethnicity, Identity, Migration: The South Asian Context. Ed. Milton Israel and N.K. Wagle Toronto: Centre for South Asian Studies, University of Toronto, 1993. 269-290.

"Repatriates Get Set for Departure Tomorrow" The Daily Chronicle 3 Sept 1955. N. pag. "Resurgent Leaves" The Daily Argosy, 5 September 1955: 6.

Rodney, W. A History of Guyanese Working People, 1881-1905. Baltimore, Maryland: John Hopkins University Press, 1981.

Rohlehr, Gordon. Calypso and Society in Pre-Independence Trinidad. Tunapuna, Trinidad: Selfpublished, 1990.

---. "The Culture of Williams: Context, Performance, Legacy." Callaloo. 20.4 (1997): 849888.

Rowley, Hazel. "A Sort of Homecoming.” The Nation. (September 11, 2006 issue). 18

September 2006. <http://www.thenation.com/doc/20060911/rowley/2>

Ruhomon, Joseph. "Centenary Notes and Comment" Centenary Celebration of the Arrival of 
Indians to British Guiana (1838-1938). By British Guiana East Indian Association. Ed.

Baytoram Ramharack.1938. San Juan Trinidad: Chakra Publishing House, 2001. 58-81.

Ruhomon, Peter. "The Building of Greater India" Centenary Celebration of the Arrival of

Indians to British Guiana (1838-1938). By British Guiana East Indian Association. Ed.

Baytoram Ramharack.1938. San Juan Trinidad: Chakra Publishing House, 2001. 105110.

Samaroo, Brinsley. "The Indian Connection: The Influence of Indian Thought and Ideas on East Indians in the Caribbean." India in the Caribbean. Ed. David Dabydeen and Brinsley Samaroo. London: Hansib, 1987. 43-59.

Schuler, Monica. Transcript. "Liberated Central Africans in Nineteenth-Century Guyana." Harriet Tubman Seminar. York University, Toronto 24 January 2000. 18 September 2006. <http://www.yorku.ca/nhp/seminars/seminars/schuler.doc.>

Scoble, John. Hill Coolies: A brief exposure of the deplorable condition of the hill coolie in British Guiana and Mauritius and of the nefarious means by which they were induced to resort to these colonies. London, 1840.

Seecharan, C. India and the Shaping of the Indo-Guyanese Imagination 1890s-1920s. Leeds, England: Peepal Tree, 1993.

---. "The Shaping of the Indo-Caribbean People: Guyana and Trinidad to the 1940s." Asia in the Caribbean. Ed. Frank Birbalsingh. Spec.issue of Journal of Caribbean Studies.14.1\&2 (1999-2000): 61-92.

Selvon, Samuel. An Island is a World. 1955. Toronto: TSAR 1993.

--.. "Three Into One Can't Go - East Indian, Trinidadian, West Indian." India in the Caribbean. Ed. David Dabydeen and Brinsely Samaroo. London: Hansib, 1987. 13-24. 
Sharma, S.L. "Perspectives on Indians Abroad." The Indian Diaspora: Dynamics of Migration.

Ed. N. Jayaram. New Delhi: Sage Publications, 2004. 44-65.

Shepherd, Verene. "Poverty, Exploitation and Agency Among Indian Settlers in Jamaica:

Evidence from Twentieth Century Letters." Asia in the Caribbean. Ed. Frank Birbalsingh.

Spec.issue of Journal of Caribbean Studies. 14.1\&2 (1999-2000): 93-111.

---. Maharani's Misery: Narratives of a Passage from India to the Caribbean. Kingston, Jamaica: University of the West Indies Press, 2002.

Simpson, Hyacinth. "Responding to MaComere queries and other stuff." Email to the author 20 January 2006.

---. "Testing the Limits of Community." Indo-Caribbean World. November 2005. N. pag.

---. Personal Communications. 24 August 2006.

Singh, Simboonath. "Cultures of Exile: Diasporic Identities and the 'Imaginations' of Africa and India in the Caribbean." Identity: An International Journal of Theory and Research. 1.3 (2001): 289-305.

Sugiman, Pamela. “Memories of Internment: Narrating Japanese-Canadian Women's Life Stories." Diaspora, Memory and Identity: A Search for Home. Ed. Vijay Agnew. Toronto: University of Toronto Press, 2005. 48-80.

Taylor, P. The Narrative of Liberation: Perspectives on Afro-Caribbean Literature, Popular Culture and Politics. Ithaca, New York: Cornell University Press, 1989.

Tinker, Hugh. The Banyan Tree: Overseas Emigrants from India, Pakistan, and Bangladesh Oxford, UK: Oxford University Press, 1977.

---. A New System of Slavery: The Export of Indian Labour Overseas 1830-1920

London: Oxford University Press, 1974. 
Tiwari, Rampersaud. "Contentment, compassion, tolerance: Hallmarks of the life of Chabilal Ramcharan - May 12, 1918 - July 16, 2006." Indo Caribbean World. 16 August 2006: 21.

Wharton, W., Parbhu Sawh, and Joseph Luckhoo. "Status of Indians Abroad: A Colony for India." Georgetown, Guyana. n.d.

Williams, Eric. From Columbus to Castro: The History of the Caribbean 1492-1969. London: Deutsch, 1970. 


\section{Notes}

${ }^{1}$ Throughout the paper, British Guiana (or Guiana for short) refers to the country under colonisation. In reference to the post-independence era, Guyana is used. Similarly, Guianese is used to refer to a resident of British Guiana and Guyanese to refer to a citizen of Guyana.

${ }^{2}$ For instance, sailing onboard the ship Komagata Maru in 1914, potential Indian immigrants (and British subjects) attempted to challenge Canada's racist and exclusionary laws (e.g. the continuous journey regulation), but were not allowed to disembark in Vancouver and were forcibly turned away, only to face reprisals from British authorities upon their return to India (Kelley and Trebilcock 150-152).

${ }^{3}$ Indentureship was described as "a monstrous, rotten system, rooted upon slavery, grown in its stale soil, emulating its worst abuses, and only the more dangerous because it presents itself under false colours, whereas slavery bore the brand of infamy upon its forehead" (Chief Justice Beaumont qtd. in Mangru, Benevolent 3).

${ }^{4}$ However, emancipated Africans returned during a similar time period as returning Indian indentureds. Nath cites the first African return ship from British Guiana as the Growler, sailing in 1847 to Sierra Leone (33). The Daily Chronicle noted an African return ship sailing from Trinidad to Liberia in the same year as the M.V. Resurgent ("250 Trinidadians"). An interesting contrast to the experiences of the last repatriates might be the invitation to diasporic Africans extended by President Kwame Nkrumah (unlike Nehru's response), shortly after Ghana's independence in 1957 (Rowley 2).

${ }^{5}$ See Tinker's A New System of Slavery for a comprehensive discussion of Indentureship as a form of neo-slavery. ${ }^{6}$ The Indentureship system continued, with brief suspensions due to the advocacy of the Anti-Slavery Society, until 1917 (Laurence 3); the last indentureship contracts in Guiana were cancelled in 1920 (Nath 130).

${ }^{7}$ Coolie is an ugly reference to Indians' subordinate status. British rulers considered "coolies" ill-suited to the climate of countries such as Canada (Kelley and Trebilcock 147), but well-suited to labour in the tropics.

${ }^{8}$ Unlike other former colonies, the Caribbean never had a history of forced repatriation.

${ }^{9}$ After protest from indentured labourers and the intervention of the Indian government, Ordinance No. 25 of 1891 (which came into effect in 1894) provided free return passage for children of any age (Laurence 382), explaining the presence of adult children traveling with their parents on the M.V.Resurgent.

${ }^{10}$ The end of Indentureship did not spell the end of desired ties between Guiana and India; an Indian "Colonisation Scheme" for British Guiana was given consideration in the 1920s (Wharton, Sawh and Luckhoo).

${ }^{11}$ Rum was made from the by-products of sugar and available on credit from the estate (Laurence 257). If an indentured labourer amassed significant debt (for example due to alcoholism), he would have great difficulty accumulating enough savings for return passage (Simpson).

12 “...that the coolies were locked up in the sick house and the next morning they were flogged with a cat-o'-nine tails... they were tied to the post... and I cannot remember how many licks; he gave them enough. I saw blood... [the planters] rubbed salt pickle on their backs" (Ceasar qtd. in Nath 15).

13 "On arrival at the depot, the labourer was ready to begin the process of becoming an indentured coolie... he was surrounded [for the first time] by folk whose speech was unintelligible, and whose physical characteristics appeared foreign, while their ways of eating and other habits would all seem wrong. However, he would have to conform to these strange ways..." (Tinker, New System 137; 140)

${ }^{14}$ Mittleholzer recalls the homogenizing impact of the term, "whether they were labourers or eventually became doctors or barristers or civil servants" they were all called coolies (Mittelholzer qtd. in Seecharan, Indo-Guyanese $11)$.

${ }^{15}$ Or as Mishra bluntly states, "Indenture introduced us to industrialization - steam ships, sugar mills, trains - and quickly transformed us from caste-ridden, illiterate rejects to an enlightened progressive and a relatively homogeneous 'race.'"

${ }^{16}$ Trinidad Immigration Report for 1871: “...the work is hard, monotonous and in high canes may almost be called solitary; he [the indentured labourer] loses heart...cold, wet, fatigued...till at the end of his first year it is found that his work has not paid for his rations..." (Tinker, New System 182).

${ }^{17}$ At Emancipation, the Afro-Guianese population comprised the vast majority of Guiana's population, 98,000 out of a total population of 100,600 . Until 1846, the relative scarcity of labour enabled freed Afro-Guianese labourers to bargain with plantation owners (Schuler 1).

${ }^{18}$ Dr. Eric Williams first used the term "recalcitrant minority" following his defeat in the 1958 Trinidadian national elections (Rohlehr 857). Although Rohlehr suggests the term had a broad connotation, "recalcitrant minority" is commonly understood to mean Indo-Caribbean.

${ }^{19}$ The following lyrics ridicule those who did not repudiate connections to India: 


\section{Me work for me money me go back to me country \\ Gi.Sita Ram Gi \\ Cook am choti baigan talcarry \\ Gi Sita Ram Gi \\ Me tell you me go me going home tomorrow \\ Gi Sita Ram Gi \\ Me have the privilege to live Rambat village \\ Gi Sita Ram Gi (Tiger qtd. in Roehlehr 256)}

${ }^{20}$ An article appeared entitled "“Back to India Move' Waste of Money" in the British Guianese newspaper The Daily Chronicle (4). According to the article, Sugrim Singh, an elected Member of Legislative Council, suggested most returnees were "decrepit mendicants."

${ }^{21}$ The term "diasporic archive" is borrowed from Mishra ("Impossible Mourning" 25).

22 The position of Personnel Manager was higher in status than Immigration Agent-General, before the department was absorbed into the General Register Office. As Personnel Manager, Ramcharan was the "de facto deputy head of the Ministry of Housing" (Tiwari 21).

${ }^{23}$ A good example is the celebration of Indian Arrival Day. Although Lokaisingh-Meighooo views Arrival Day celebrations as a sign of ambivalent diasporic identity (15), conscious recovery of such connections can help work through notions of ambivalence (Hall 235).

${ }^{24}$ In the body of his text, Laurence cites the last return ship as sailing in 1947 (381); however in his Appendix he lists a return ship as sailing in 1955 presumably the Resurgent (539).

${ }^{25}$ Exodus and departures especially to the east are rarely reported (Tinker, Banyan 138), and "to date no systematic study exists on Indian repatriation in Caribbean" (Singh 298).

${ }^{26}$ Fifteen individuals onboard the Resurgent arrived as free migrants after Indentureship (Guyana Register).

${ }^{27}$ Khan's description is similar to Naipaul's memory: "Many Indians, after they had served their indenture, had found themselves destitute and homeless. Such people, within my memory, slept at night in the Port of Spain squares." (Finding 61)

${ }^{28}$ Walcott described the cane fields as a "green prison" where indentured labourers served time in his 1992 Nobel speech.

${ }^{29}$ The Immigration Fund was established in 1864, to cover the cost of receiving Indians in the colony, maintaining the Immigration Department and its agencies abroad, and to contain the cost of repatriation and incentives to reindenture (Ramharack 118).

${ }^{30}$ Ramcharan recalled translating not only official documents from English to Hindi, but also translating the concerns of estate workers, spoken in a creole "coolie" English to standard English, for the courts/Immigration Office.

31 "You have son/ you have daughter/ you cyan leave it to go/ ... me no having nutting India/ all e have have chinedad" (Bharath qtd. in Mahabir 108); "me fadder say/ come go/ come go India/ I say/ no/ I studying dem cheren." (Maharani qtd. in Mahabir 88). Close family ties discouraged many from leaving the colony.

${ }^{32}$ The papers of the day attributed the cost of chartering the ship at $\$ 280,000$ (GYD), three times the cost of prior return ships ("Back to India Waste").

${ }^{33}$ The British East India Company is named as the ship's owner by The Daily Chronicle, however it is not clear whether this company has links to the same British East India Company which ruled India during colonial times

${ }^{34}$ The last Trinidadian return ship sailed in 1936 according to Laurence (540).

${ }^{35}$ The M.V. Resurgent's Register does not record any repatriates from Enmore Sugar Estate (Guyana Register).

${ }^{36}$ Later in 1955, Burnham would split from Jagan, causing a racial split in Guianese/Guyanese politics (Naipaul, The Middle Passage 93).

${ }^{37}$ Singh's choice of pronoun exposes the break in diaspora between those who returned and those who stayed in Guiana.

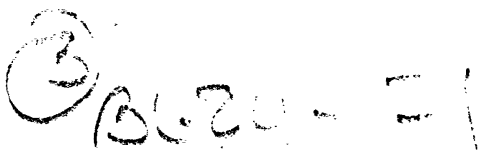

